\title{
A systematic study of Dryopteris subg. Erythrovariae (H. Itô) Fraser-Jenk. (Dryopteridaceae) in Korea
}

\author{
Sang-Jun Lee ${ }^{1}$ and Chong-Wook Park* \\ School of Biological Sciences, College of Natural Sciences, Seoul National University, Seoul 151-747, Korea \\ ${ }^{1}$ National Biodiversity Center, National Institute of Biological Resources, Incheon 404-708, Korea \\ (Received 7 May 2015; Accepted 29 May 2015)
}

\section{한반도산 관중속 홍지네족제비고사리아속(관중과)의 분류학적 연구 \\ 이상준 ${ }^{1}$ 박종욱* \\ 서울대학교 생명과학부, ${ }^{1}$ 국립생물자원관 국가생물다양성센터}

\begin{abstract}
The taxa of Dryopteris subg. Erythrovariae are variable in morphology, resulting in taxonomic confusion in delimiting taxon boundaries. We examined the morphological characteristics of the Korean members of subg. Erythrovariae to clarify their taxonomic identities and relationships. The shapes of the blades, pinnae, and pinnule apices, the shapes and colors of the scales, and the positions of sori were useful for delimiting the Korean taxa of the subgenus. Based on the results of this study and evidence from previous studies, 13 taxa comprising 12 species and one variety of Dryopteris subg. Erythrovariae were recognized in Korea. Descriptions of all Korean taxa of the subg. Erythrovariae and a key to the species are provided. The descriptions presented here are based on field observations and the examination of some 1,000 specimens from the major herbaria of the world.
\end{abstract}

Keywords: Dryopteris, subg. Erythrovariae, morphological characters, description, key

\begin{abstract}
적 요: 관중속 홍지네족제비고사리아속에 속하는 분류군들은 형태적으로 변이가 심하여, 분류군의 한계 해 석에 대한 견해 차이가 심하다. 본 연구에서는 한반도산 홍지네족제비고사리아속의 분류군들을 대상으로 외 부형태학적 식별 형질을 검토하여 분류군들의 한계 및 유연관계를 파악하고 각 분류군들의 분류학적 실체를 규명하고자 하였다. 그 결과 엽신, 우편 및 소우편 선단부의 형태, 인편의 형태 및 색, 포막의 위치 등이 본 아속에 속하는 한반도산 분류군들을 구분하는 데 유용한 것으로 나타났다. 본 연구 결과와 기존의 결과를 종 합하여 한반도산 관중속 홍지네족제비고사리아속을 12 종 1 변종의 13 분류군으로 정리하였으며, 이들 분류군 에 대한 기재 및 종 검색표를 제시하였다. 본 연구에서 제시한 기재는 야외 관찰 결과 및 전세계 주요 표본 관에 소장된 1,000 여점의 표본에 근거하여 작성하였다.
\end{abstract}

주요어: 관중속, 홍지네족제비고사리아속, 외부형태학적 형질, 기재, 검색표

관중과(Dryopteridaceae) 관중속(Dryopteris Adans.)은 전 세계적으로 약 250 종이 보고되어 있으며, 중앙아시아, 동 남아시아 및 동아시아 온대지역에 주로 분포한다(Fraser-

\footnotetext{
*Author for correspondence: parkc@snu.ac.kr
}

http://www.pltaxa.or.kr

Copyright (C) 2015 the Korean Society of Plant Taxonomists
Jenkins, 1986; Kramer, 1990; Zhang et al., 2013). 본 속에 속 하는 식물들은 곧게 또는 비스듬하게 서거나 드물게 짧게 기는 지하경, 엽병, 중축, 우축에 붙는 인편, 최하후측 분기 또는 드물게 최하전측 분기를 하는 엽신, 함입부가 있는 둥근 신장형의 포막 등의 특징에 의해 과내 다른 속 식물 들과 구분된다(Itô, 1939; Serizawa, 1976; Fraser-Jenkins, 1986, 1989; Kramer, 1990; Iwatsuki, 1995; Lee et al., 2006; Kim et al., 2007; Zhang et al., 2013; Lee and Park, 2013, 
2014). Fraser-Jenkins (1986)는 주로 잎과 인편의 형태에 의 해 본 속 식물들을 관중아속(subg. Dryopteris), 홍지네족제 비고사리아속[subg. Erythrovariae (H. Itô) Fraser-Jenk., 국명 신칭], 계곡고사리아속[subg. Nephrocystis (H. Itô) FraserJenk., 국명신칭] 및 Pycnopteris아속[subg. Pycnopteris (T. Moore) Ching] 등 4개 아속(subgenus)과 이에 속하는 16 개 의 절(section)로 구분한 바 있다. 본 연구의 대상인 홍지네 족제비고사리아속은 현재까지 50 여 분류군이 보고되어 있으며, 주로 한국, 중국, 일본을 포함하는 동아시아 지역 에 분포하고 있다(Itô, 1939; Fraser-Jenkins, 1986; Zhang et al., 2013). 본 아속 식물들은 우축 또는 소우축 하면에 분포 하는 인편의 기부가 주머니 모양으로 부푸는 특징에 의해 속내 다른 아속과 구분된다(Fraser-Jenkins, 1986, 1989; Zhang et al., 2013).

홍지네족제비고사리아속에 속하는 분류군들은 엽신의 형태, 인편의 형태 및 색, 포자낭군의 위치 등의 형태적 차 이에 그 근거를 두고 있다(Itô, 1939; Iwatsuki, 1995; Lee et al., 2006; Kim et al., 2007; Zhang et al., 2013). 그러나 본 아 속에 속하는 분류군의 경우 종간 잡종 현상 및 무배생식 (apomixis)에 따른 배수화 현상이 빈번한 것으로 알려져 있으며 (Hirabayashi, 1974; Lee et al., 2006; Lee and Park, 2013; Hori et al., 2014), 이로 인해 형태적 변이가 심하고 식 별형질의 한계가 모호하다. 이러한 주요 식별 형질 및 분 류군의 한계 해석에 대한 견해 차이로 인해 그 분류군 수 에 있어 학자간에 심한 차이를 나타내어 (Nakai, 1952; Park, 1975; Lee, 1980; Lee, 1996; Lee 2006; Kim et al. 2007), 9 분류군(Lee, 1996)에서 16 분류군(Lee, 2006) 정도가 한반 도에 분포하는 것으로 보고되어 있다.

한편, Lee et al. (2006)은 본 아속 Dryopteris varia (L.) Kuntze complex에 속하는 한반도산 7 분류군의 생식형과 염색체 수를 조사하고, 이들 분류군들의 경계분석 (landmark analysis) 및 주요 식별형질에 대한 주성분분석 (principal components analysis) 등 수리분류학적 연구를 수 행한 바 있다. 그 결과, 엽신의 크기 및 형태, 인편의 형태 및 포막의 크기 등이 본 분류군들을 식별하는 데 유용한 것으로 나타났으며, Lee et al. (2006)은 이러한 형태 형질과 생식형 및 염색체 수에 근거하여 한반도산 삼배체 무배생 식형인 광릉족제비고사리(D. saxifragivaria Nakai)를 이배 체 유성생식형의 바위족제비고사리(D. saxifraga H. Itô)와 이배체 무배생식형의 산족제비고사리[D. bissetiana (Baker) C. Chr.] 간의 잡종으로 인식한 바 있다. 또한, Lee and Park (2013)은 한반도산 관중속 식물의 핵 및 엽록체 DNA의 염 기서열을 분석하여, D. varia (L.) Kuntze complex에 속하는 한반도산 분류군들의 경우, 동질배수화(autopolyploidization) 및 종간 잡종에 의한 이질배수화(allopolyploidization) 현상 등을 수반하는 망상 진화가 일어난 것을 밝힌 바 있다. 또 한, Lee and Park (2014)은 포자 미세구조를 관찰하여, 한반 도산 관중속 분류군들의 포자외막이 주름형, 자상돌기형,
침상형 등 크게 3종류의 표면 무늬로 구분되는 것을 밝힌 바 있으나, 한반도산 홍지네족제비고사리아속에 대한 종 합적인 검토가 수행된 바 없다.

따라서 본 연구에서는 관중속 홍지네족제비고사리아 속에 속하는 한반도산 분류군의 외부형태학적 식별 형질 을 재검토하여 분류군들의 한계 및 유연관계를 파악하고 각 분류군의 분류학적 실체를 규명하고자 하였으며, 본 아속에 속하는 한반도산 분류군들의 분류학적 처리와 함 께 검색표를 제시하였다.

\section{재료 및 방법}

\section{재료}

본 연구에 사용한 재료는 1999년부터 2014년까지 채집 하여 제작한 건조 표본 및 경북대학교 $(\mathrm{KNU})$, 국립생물자 원 관(KB), 서울대학교(SNU), 서울대학교 농업생명과학 대학(SNUA), 성균관대학교(SKK), 안동대학교(ANH), 이 화여자대학교 $(\mathrm{EWH})$, 전남대학교 $(\mathrm{CNU})$, 전북대학교 (JNU) 및 제주대학교(JNUB) 등의 국내 표본관과 Institute of Botany, Chinese Academy of Sciences (PE), Kyoto University (KYO), Harvard University (GH), Muséum National d'Histoire Naturelle (P), Nationaal Herbarium Nederland, Leiden Univeristy (L), New York Botanical Garden (NY), Royal Botanic Garden, Edinburgh (E), Royal Botanic Gardens, Kew (K), Taiwan Forestry Research Institute (TAIF), Universität Zürich $(\mathrm{Z})$ 등 해외 표본관에 소장된 1,000 여점 의 건조 표본 또는 표본 사진을 사용하였다(Appendix). 본 연구 기간 중에 채집한 개체들의 표본은 서울대학교 (SNU) 및 국립생물자원관(KB) 표본관에 확증표본으로 소장하였다(Appendix).

\section{방법}

관중속 홍지네족제비고사리아속에 속하는 분류군들의 외부형태형질의 관찰은 직접 채집한 개체들과 상기한 국 내외 주요 표본관에 소장되어 있는 표본들을 사용하여 수 행하였다. 이들 표본은 원기재문, 기준표본의 사진 및 도 해를 참조하여 각 분류군으로 동정, 분류하였다. 이로부 터 본 아속 분류군들의 주요 식별 형질로 여러 학자들에 의해 사용된 형질들과 본 연구에서 각 분류군을 구분하는 데 유용한 것으로 판단된 형태 형질을 측정, 분석하였다.

\section{결과 및 고찰}

\section{외부형태}

홍지네족제비고사리아속에 속하는 한반도산 분류군들 은 상록성 또는 낙엽성 식물로, 우축 또는 소우축에 붙는 인편의 기부가 주머니처럼 부푸는 특징에 의해 관중속내 다른 아속들과 뚜렷이 구분된다. 


\section{1) 지하경}

관중속 식물의 지하경은 곧게 또는 비스듬하게 서거나 드물게 짧게 기는 것으로 알려져 있으며 (Itô, 1939; FraserJenkins, 1986; Kramer, 1990; Iwatsuki, 1995; Zhang et al., 2013), 본 연구 결과 홍지네족제비고사리아속에 속하는 한 반도산 분류군의 지하경은 곧게 또는 비스듬하게 선다.

\section{2) 엽신}

본 연구 결과, 엽신의 전체 형태 및 결각 상태는 한반도 산 홍지네족제비고사리아속에 속하는 분류군들을 구분 하는 데 유용한 것으로 나타났다(Fig. 1).

전체 형태: 본 아속에 속하는 한반도산 분류군의 엽신 전체 형태는 장타원형, 피침형, 난형 또는 오각형으로 다 양하며 (Fig. 1), 아물고사리(D. amurensis Christ), 홍노족제
비고사리[D. formosana (Christ) C. Chr.] 및 족제비고사리 [D. varia (L.) Kuntze]는 오각형의 엽신을 가지는 특징에 의 해 나머지 한반도산 분류군들과 뚜렷이 구분된다(Fig. 1FH). 한편, 애기지네고사리[D. decipiens var. diplazioides (Christ) Ching]는 피침형이며 (Fig. 1A), 큰족제비고사리( $D$. podouensis Ching) 및 애기족제비고사리(D. sacrosancta Koidz.)는 난형이다(Fig. 1I, J). 나머지 분류군들의 경우 장 타원형 내지 난형 (Fig. 1B-E) 또는 난형 내지 피침형으로 (Fig. $1 \mathrm{~K}-\mathrm{M})$, 개체간 변이가 존재한다.

결각 상태: 한반도산 홍지네족제비고사리아속 분류군 들은 1-4회 우상복엽을 가지며 (Fig. 1), 애기지네고사리 의 엽신은 1 회 우상복엽인 특징에 의해 나머지 분류군들 과 뚜렷이 구분된다(FIg. $1 \mathrm{~A})$. 한편, 제주지네고사리 $[D$. championii (Benth.) C. Chr. ex Ching], 엷은지네고사리(D.


G



D



$E$







I



$J$



K

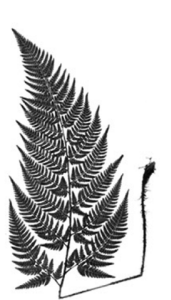

L



M



Fig. 1. Representative leaves of Dryopteris subg. Erythrovariae in Korea. A. D. decipiens var. diplazioides (C.-H. Kim s.n.); B. D. championii (T. Nakaike s.n.); C. D. kinkiensis (C. S. Lee \& Y. S. Kim 060653); D. D. fuscipes (S.-J. Lee 1210); E. D. erythrosora (H. T. Im et al 70191$)$; F. D. amurensis (Y. Zhang 14); G. D. formosana (S.-J. Lee 1373); H. D. varia (S.-J. Lee 622); I. D. podouensis (S.-J. Lee 611); J. D. sacrosancta (S.-J. Lee 500); K. D. bissetiana (S.-J. Lee 383); L. D. saxifraga (S.-J. Lee 402); M. D. saxifragivaria (S.-J. Lee 539). 
kinkiensis Koidz. ex Tagawa), 큰지네고사리(D. fuscipes C. Chr.) 및 홍지네고사리[D. erythrosora (D. C. Eaton) Kuntze] 는 2회 우상복엽이고 (Fig. 1B-E), 홍노족제비고사리와 아 물고사리는 3-4회 우상복엽이다(Fig. $1 \mathrm{~F}, \mathrm{G})$. 나머지 한반 도산 분류군들의 엽신은 2-3회 우상복엽으로 개체간 변 이가 존재한다(Fig. $1 \mathrm{H}-\mathrm{M})$.

\section{3) 우편}

Franser-Jenkins (1986)는 본 아속에 속하는 분류군들을 인편 및 기부우편의 형태에 근거하여 홍지네고사리절(sect. Erythrovariae H. Itô, 국명신칭), 족제비고사리절(sect. Variae Fraser-Jenk., 국명신칭) 및 Politae절(sect. Politae Fraser-Jenk.) 등 3 개의 절로 구분하였다. 한반도에는 기부우편의 기부외측 기부소우편의 길이가 인접한 소우편보다 작거나 거의 같은 홍지네고사리절과 기부우편의 기부외측 소우편의 길이가 인접한 소우편보다 긴 족제비고사리절에 속하는 분류군들 이 보고되어 있다(Park, 1975; Lee, 1980; Lee, 1996; Lee 2006; Kim et al., 2007). 본 연구 결과, 아물고사리, 홍노족제비고사 리, 족제비고사리, 큰족제비고사리, 애기족제비고사리, 산족 제비고사리, 바위족제비고사리 및 광릉족제비고사리의 기 부우편은 기부외측 소우편의 길이가 인접한 소우편보다 긴 특징에 의해 나머지 분류군들과 뚜렷이 구분된다(Fig. $1 \mathrm{~F}-\mathrm{M}$ ).

\section{4) 소우편}

소우편 선단부의 형태는 본 아속의 일부 분류군을 구
분하는데 유용한 것으로 밝혀졌다(Table 1). 제주지네고 사리, 엷은지네고사리 및 큰지네고사리의 소우편 선단부 는 원두 내지 둔두인 특징에 의해 본 아속내 나머지 한반 도산 분류군들과 뚜렷이 구분된다(Table 1). 한편, 아물고 사리, 족제비고사리, 큰족제비고사리, 애기족제비고사리, 산족제비고사리, 바위족제비고사리 및 광릉족제비고사 리는 예두이며, 홍노족제비고사리는 예두 내지 점첨두이 다(Table 1). 홍지네고사리의 경우 대부분의 개체에서 예두 또는 둔두이나, 일부 개체에서 드물게 원두이다(Table 1).

\section{5) 인편}

관중속에 속하는 분류군들은 지하경, 엽병, 중축, 우축, 소우축 등에 인편이 붙으며, 인편의 형태는 관중속내 분 류군을 구분하는 데 중요한 형질로 사용되어 왔다(Itô, 1939; Park, 1975; Serizawa, 1976; Fraser-Jenkins, 1986, 1989; Iwatsuki, 1995; Lee et al, 2006; Zhang et al., 2013). 본 연구 결과, 홍지네족제비고사리아속 식물은 우축 또는 소우축 하면에 기부가 주머니처럼으로 부푸는 인편이 붙는 특징 이 있으며, 특히 엽병과 중측에 붙는 인편의 형태와 색 및 중축 인편의 가장자리 형태는 홍지네족제비고사리아속 의 분류군들을 구분하는 데 유용한 것으로 밝혀졌다(Figs. 2, 3; Table 1).

엽병 인편: 본 아속 한반도산 분류군들의 엽병에는 선 형, 피침형 또는 난형의 인편이 붙는다(Fig. 2). 족제비고

Table 1. Comparison of the shape and/or color of pinnules and scales, and the position of sori between Korean taxa of Dryopteris subg. Erythrovariae.

\begin{tabular}{|c|c|c|c|c|}
\hline Taxon & Apex of pinnules & Color of scales & Margin of rachis scales $^{\mathrm{a}}$ & Position of sori \\
\hline \multicolumn{5}{|l|}{ Dryopteris } \\
\hline \multicolumn{5}{|l|}{ decipiens } \\
\hline var. diplazioides & - & blackish brown & $\mathrm{E}$ & pericostal \\
\hline championii & round or obtuse & $\begin{array}{l}\text { reddish brown to dark } \\
\text { brown }\end{array}$ & $\mathrm{P}$ & medial to submarginal \\
\hline kinkiensis & round or obtuse & dark brown & $\mathrm{P}$ & submedial to medial \\
\hline fuscipes & round or obtuse & reddish brown & $\mathrm{E}$ & pericostal to submedial \\
\hline erythrosora & acute or obtuse & blackish brown & $\mathrm{E}$ & submedial to medial \\
\hline amurensis & acute & pale brown & $\mathrm{E}$ & medial to submarginal \\
\hline formosana & acute or acuminate & blackish brown or black & $\mathrm{E}$ & medial to submarginal \\
\hline varia & acute & reddish brown & $\mathrm{P}$ & medial to submarginal \\
\hline podouensis & acute & blackish brown or black & $E$ or rarely $P$ & medial to submarginal \\
\hline sacrosancta & acute & blackish brown or black & $\mathrm{P}$ & submedial to medial \\
\hline bissetiana & acute & blackish brown or black & E or rarely $\mathrm{P}$ & submedial to medial \\
\hline saxifraga & acute & blackish brown or black & $E$ or rarely $P$ & submedial to medial \\
\hline saxifragivaria & acute & blackish brown or black & $\mathrm{E}$ or rarely $\mathrm{P}$ & submedial to medial \\
\hline
\end{tabular}

a. E: entire, P: with irregular projections. 
A



$\mathrm{H}$



B



C



D



E





G



I J





$\mathrm{K}$



$\mathrm{L}$



M



$5 \mathrm{~mm}$

Fig. 2. Representative stipe scales of Dryopteris subg. Erythrovariae in Korea. A. D. decipiens var. diplazioides (C.-H. Kim s.n.); B. D. championii (T. Nakaike s.n.); C. D. kinkiensis (C. S. Lee \& Y. S. Kim 060653); D. D. fuscipes (S.-J. Lee 1210); E. D. erythrosora (H. T. Im et al 70191); F. D. amurensis (Y. Zhang 14); G. D. formosana (S.-J. Lee 1373); H. D. varia (S.-J. Lee 622); I. D. podouensis (S.-J. Lee 611); J. D. sacrosancta (S.-J. Lee 500); K. D. bissetiana (S.-J. Lee 383); L. D. saxifraga (S.-J. Lee 402); M. D. saxifragivaria (S.-J. Lee 539).

사리, 큰족제비고사리, 산족제비고사리, 바위족제비고 사리 및 광릉족제비고사리의 엽병 인편은 선형이며 (Fig. 2H, I, K-M), 아물고사리의 인편은 난형으로 (Fig. $2 \mathrm{~F})$, 나머지 분류군들과 뚜렷이 구분된다. 한편, 나머지 한반도산 분류군들의 엽병 인편은 피침형이다(Fig. $2 \mathrm{~A}-$ E, G, J).

중축 인편: 본 아속 한반도산 분류군의 중축에는 선형 또는 피침형의 인편이 붙는다(Fig. 3). 큰지네고사리, 홍지 네고사리, 홍노족제비고사리, 족제비고사리, 큰족제비고 사리, 산족제비고사리, 바위족제비고사리, 광릉족제비고 사리는 선형으로 (Fig. 3D, E, G-I, K-M), 나머지 분류군들 과 뚜렷이 구분된다. 나머지 한반도산 분류군들의 중축 인편은 피침형이다(Fig. $3 \mathrm{~A}-\mathrm{C}, \mathrm{F}, \mathrm{J})$. 한편, 대부분의 분류 군들에서 중축 인편은 위쪽을 향하거나 비스듬히 붙으나 (Fig. 3A-K), 바위족제비고사리의 경우 중축의 인편이 아 래쪽을 향하다가 위쪽으로 휘어지는 갈고리 모양이며 (Fig. $3 \mathrm{~L}$ ), 광릉족제비고사리는 위쪽을 향하는 인편과 갈 고리 모양으로 휘어지는 인편이 한 개체내에서 섞여서 붙 는다(Fig. 3M).
중축 인편 가장자리: 본 아속내 한반도산 분류군들의 중축 인편의 가장자리 형태는 전연이거나, 불규칙한 거 치가 있다(Fig. 3; Table 1). 제주지네고사리, 엷은지네고 사리, 족제비고사리 및 애기족제비고사리의 중축 인편 가장자리에는 불규칙한 거치가 있어 나머지 한반도산 분 류군들과 뚜렷이 구분된다(Fig. 3B, C, H, J; Table 1). 한편 나머지 분류군들의 중축 인편은 전연이거나 가장자리에 매우 드물게 불규칙한 거치가 있다(Fig. $3 \mathrm{~A}, \mathrm{D}-\mathrm{G}, \mathrm{I}, \mathrm{K}-\mathrm{M}$; Table 1).

중축 인편 색: 중축 인편 색의 경우, 아물고사리는 담갈 색이며, 애기지네고사리, 홍지네고사리, 홍노족제비고사 리, 큰족제비고사리, 애기족제비고사리, 산족제비고사리, 바위족제비고사리 및 광릉족제비고사리는 흑갈색 또는 흑색으로 본 아속에 속하는 나머지 한반도산 분류군들과 구분된다(Table 1). 한편, 나머지 분류군들은 적갈색 또는 암갈색이다(Table 1).

\section{6) 포자낭군, 포막}

한반도산 홍지네족제비고사리아속의 포자낭군은 원형 
A



B



C

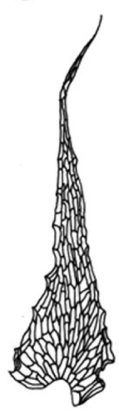

D

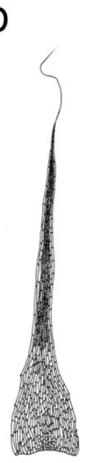

E



F



G






M



Fig. 3. Representative rachis scales of Dryopteris subg. Erythrovariae in Korea. A. D. decipiens var. diplazioides (C.-H. Kim s.n.); B. D. championii (T. Nakaike s.n.); C. D. kinkiensis (C. S. Lee \& Y. S. Kim 060653); D. D. fuscipes (S.-J. Lee 1210); E. D. erythrosora (H. T. Im et al 70191); F. D. amurensis (Y. Zhang 14); G. D. formosana (S.-J. Lee 1373); H. D. varia (S.-J. Lee 622); I. D. podouensis (S.-J. Lee 611); J. D. sacrosancta (S.-J. Lee 500); K. D. bissetiana (S.-J. Lee 383); L. D. saxifraga (S.-J. Lee 402); M. D. saxifragivaria (S.-J. Lee 539).

으로 맥 위에 배생하며, 함입부가 있는 둥근 신장형의 포 막이 숙존한다. 본 연구 결과, 포자낭군의 위치는 일부 분 류군을 구분하는 데 유용한 것으로 나타났다(Table 1). 애 기지네고사리 및 큰지네고사리는 중륵 근처 (pericostal) 또는 중륵과 가장자리의 중간에서 중륵에 치우쳐 (submedial) 달리며, 제주지네고사리, 아물고사리, 홍노족 제비고사리, 족제비고사리 및 큰족제비고사리는 중륵과 가장자리의 중간 (medial) 내지 보다 가장자리에 치우쳐 (submarginal) 달리는 특징에 의해 뚜렷이 구분된다(Table 1). 나머지 한반도산 분류군들의 포자낭군은 중륵과 가장 자리의 중간 내지 중륵과 가장자리의 중간에서 보다 중륵 에 치우쳐 달린다(Table 1).

\section{7) 포자}

관중속에 속하는 식물의 포자외막 형태는 일부 분류군 들을 구분하는 데 유용한 것으로 보고되어 있다(Tryon and Lugardon 1991; Lee and Park, 2014). Lee and Park (2014)은 관 중속 한반도산 분류군의 포자 미세구조를 관찰하여, 이들 분류군의 포자를 포자외막의 형태에 근거하여 주름형, 자 상돌기형, 침상형 등 크게 3종류로 구분한 바 있다. 본 아속 에 속하는 한반도산 분류군들은 주름형 또는 침상의 포자
외막을 가지며, 침상형의 포자외막은 홍노족제비고사리에 국한되어 나타난다(Lee and Park, 2014). 한편, 제주지네고사 리 및 엷은지네고사리는 포자외막의 미세무늬가 뚜렷하지 않는 반면, 나머지 분류군들은 뚜렷한 망상형의 미세무늬 를 가지는 특징에 의해 구분된다(Lee and Park, 2014).

\section{분류학적 처리}

본 연구에서는 한반도산 관중속 분류군에 대한 상기 외 부형태학적 연구 결과 및 포자 형태에 관한 연구 결과 (Lee and Park, 2014)와 홍지네족제비고사리아속에 속하는 한반도산 D. varia complex에 관한 수리분류학적 연구 결 과 (Lee et al., 2006) 및 분자계통학적 연구 결과 (Lee and Park, 2013)에 근거하여, 한반도산 관중속 홍지네족제비고 사리아속 식물을 12 종 1 변종의 13 분류군으로 정리하였다. 이들 분류군의 분류학적 처리는 다음과 같다.

Dryopteris subg. Erythrovariae (H. Itô) Fraser-Jenk., Bull. Brit. Mus. (Nat. Hist.), Bot. 14: 195, 1986. D. sect. Erythrovariae H. Itô, Bot. Mag. (Tokyo) 50: 32, 1936. D. subsect. Erythrovariae (H. Itô) H. Itô in Nakai \& Honda, Nov. Fl. Jap. 4: 37, 1939. D. ser. Erythrovariae (H. Itô) S. G. Lu, 
Guihaia 19(2): 112, 1999. Type. D. erythrosora (D. C. Eaton) Kuntze (lectotype, designated by Itô in Nakai \& Honda, Nov. Fl. Jap. 4: 37, 1939).

\section{국명: 홍지네족제비고사리아속}

상록성 또는 낙엽성 초본으로, 땅에 자란다. 지하경은 곧게 또는 비스듬하게 서고, 인편이 빽빽하게 붙는다. 잎은 영양엽과 포자엽이 동일한 1종류이고, 모여 나거 나 붙어 난다. 엽병은 인편이 빽빽하게 또는 성글게 붙 는다. 엽병의 인편은 선형, 피침형 또는 난형으로, 주로 갈색 또는 흑색이고 간혹 붉은 빛이 돌며, 기부가 편평 하고, 전연 또는 가장자리에 불규칙한 거치가 있다. 엽 신은 최하후측 분기하고, 장타원형, 피침형, 난형 또는 오각형이며, 1-4회 우상복엽이고, 상부를 향해 점진적 또는 다소 갑자기 좁아지며, 혁질 또는 드물게 초질이다. 중축은 상면에 홈이 있고, 각 우축의 홈과 연속적이며, 인편이 빽빽하게 또는 성글게 붙는다. 중축의 인편은 선 형, 피침형 또는 난형이고, 갈색 또는 흑색이며, 기부가 편평하거나 주머니 모양으로 부풀고, 전연 또는 가장자 리에 불규칙한 거치가 있다. 우편은 선형, 난형 또는 피 침형이며, 점첨두 또는 미두이다. 우축은 인편이 빽빽하 게 또는 성글게 붙으며, 인편은 선형 내지 피침형으로, 기부가 주머니 모양으로 부푼다. 최종열편은 피침형, 난 형 또는 타원형이고, 거의 전연이거나 가장자리에 둔거 치, 차아상 거치 또는 침상 거치가 있으며, 원두, 둔두 또 는 예두이다. 엽맥은 유리맥이고, 최종열편의 측맥은 차 상분지한다. 포자낭군은 원형이고, 맥위에 배생하며, 우 편 또는 열편의 중륵과 가장자리 사이에 1 열 또는 2 열로 배열하고 포막이 있다. 포막은 함입부가 있는 둥근 신장 형이며, 전연 또는 거의 전연이고, 숙존한다. 포자는 포 자낭당 32 개 또는 64 개이며, 단지형이고, 포자외막은 주 름지거나 드물게 침상이다. 염색체 수 $x=41(2 n=82$, 123, 164).

분류군 수: 약 50 종(한반도 12종 1변종)

분류학적 고찰: 홍지네족제비고사리아속에 속하는 식 물들은 우축 또는 소우축에 하면에 붙는 인편의 기부가 주머니 모양으로 부푸는 특징에 의해 속내 다른 아속과 뚜렷이 구분된다(Fraser-Jenkins, 1986, 1989). 본 연구 결과 엽신 및 우편의 형태, 소우편 또는 최종열편의 선단부 형 태, 엽병 인편 및 중축에 붙는 인편의 형태 및 색, 중축 인편 의 가장자리 형태, 포막의 위치 등이 본 아속에 속하는 한 반도산 분류군들을 구분하는 데 유용한 것으로 나타났다.

\section{한국산 관중속 홍지네족제비고사리아속의 종 검색표}

1. 엽신은 1 회 우상복엽이다

1) D. decipiens (애기지네고사리)
1. 엽신은 2회 우상복엽 또는 그 이상 분열한다.

2. 기부우편의 기부외측 기부소우편의 길이는 인접한 소우편보다 작거나 거의 같다.

3. 중축의 인편은 피침형이고, 가장자리에 불규칙한 거치가 있고, 연한 막질이다. 소우편의 상면에 배 수조직이 없다.

4. 엽신 상면에 윤기가 있다. 중축의 인편은 빽빽하 게 붙는다. 포자낭군은 최종열편의 중륵과 가장 자리의 중간 내지 가장자리에 치우쳐 붙는다

2) D. championii (제주지네고사리)

4. 엽신 상면에 윤기가 없다. 중축의 인편은 다소 성 글게 붙는다. 포자낭군은 최종열편의 중륵과 가 장자리의 중간 내지 중륵에 치우쳐 붙는다

3) D. kinkiensis (엷은지 네고사리)

3. 중축의 인편은 선형이고, 전연 또는 드물게 가장자 리에 불규칙한 거치가 있으며, 다소 딱딱한 막질이 다. 소우편의 상면에 배수조직이 있다.

5. 엽병의 인편은 적갈색이다. 소우편의 선단은 원 두 또는 둔두이며, 하면의 맥은 불분명하다. 포자 낭군은 최종열편의 중륵 근처 내지 중륵과 가장 자리의 중간에서 중륵에 치우쳐 붙는다

4) D. fuscipes (큰지 네고사리)

5. 엽병의 인편은 흑갈색이다. 소우편의 선단은 대 부분 예두 또는 둔두이며, 드물게 원두이고, 하면 의 맥은 뚜렷하다. 포자낭군은 최종열편의 중륵 과 가장자리의 중간 내지 중륵에 치우쳐 붙는다 .....

5) D. erythrosora (홍지네고사리)

2. 기부우편의 기부외측 기부소우편의 길이는 인접한 소우편보다 길다.

6. 우편의 최종열편의 가장자리는 침상 거치연이다.

7. 엽병의 인편은 난형이고, 담갈색이다. 엽신의 선 단은 예두이다. 기부가 주머니 모양인 인편은 소 우축의 하부에만 성글게 붙는다

6) D. amurensis (아물고사리)

7. 엽병의 인편은 피침형이고, 흑갈색 또는 흑색이다. 엽신의 선단은 점첨두이다. 기부가 주머니 모양 인 인편은 중축, 우축 및 소우축에 빽빽히 붙는다 ...

7) D. formosana (홍노족제비고사리)

6. 우편의 최종열편은 전연이거나 가장자리에 둔거 치 또는 치아상 거치가 있다.

8. 엽신은 상부에서 갑자기 좁아지고, 최종열편의 가장자리에 치아상 거치가 있다. 포자낭군은 최 종열편의 중륵과 가장자리의 중간 내지 가장자 리에 치우쳐 붙는다.

9. 엽신은 오각형이고, 기부우편의 우축과 중축의 각도는 $40-50^{\circ}$ 이며, 기부우편의 기부외측 기부 소우편은 좁은 피침형 내지 선형이다. 엽병 인편 은 적갈색이다

8) D. varia (족제비고사리) 
9. 엽신은 난형이고, 기부우편의 우축과 중축의 각 도는 55-70이며, 기부우편의 기부외측 기부소 우편은 난형 내지 피침형이다. 엽병의 인편은 흑색이다 … 9) D. podouensis (큰족제비고사리)

8. 엽신은 상부를 향하여 점진적으로 좁아지고, 최 종열편은 전연이거나 가장자리에 둔거치가 있다. 포자낭군은 최종열편의 중륵과 가장자리의 중간 내지 중륵에 치우쳐 붙는다.

10. 중축의 인편은 피침형이고, 가장자리에 불규칙 한 거치가 있으며, 기부가 부풀지 않고 편평하 다. 포막은 직경 $0.9-1.2 \mathrm{~mm}$ 이다

10) D. sacrosancta (애기족제비고사리)

10. 중축의 인편은 선형이고, 전연 또는 드물게 가 장자리에 불규칙한 거치가 있으며, 기부가 주 머니 모양으로 부푼다. 포막은 직경 1.2$1.8 \mathrm{~mm}$ 이다.

11. 중축의 인편은 모두 곧고, 위쪽을 향하거나 비 스듬하다 ... 11) D. bissetiana (산족제비고사리)

11. 중축의 인편은 갈고리형이며, 드물게 곧은 인 편이 섞여 붙는다.

12. 중축의 인편은 모두 갈고리형이다 .......... 12) D. saxifraga (바위족제비고사리)

12. 중축의 인편은 곧고 위쪽을 향하거나 비스듬 한 것과 갈고리형이 섞여 붙는다

.... 13) D. saxifragivaria (광릉족제비고사리)

1) Dryopteris decipiens (Hook.) Kuntze, Revis. Gen. Pl. 2: 812, 1891. Nephrodium decipiens Hook., Sp. Fil. 4: 86, 1862. Aspidium decipiens (Hook.) Luerss., Bot. Jahrb. Syst. 4(4): 360, 1883. Type. China. Fujian: Fuzhou, Alexander s.n. (holotype, $\mathrm{K}$ ! [K001080810]).

Var. diplazioides (Christ) Ching, Bull. Fan Mem. Inst. Biol. 8: 476, 1938. Polystichum diplazioides Christ, Bull. Acad. Int. Géogr. Bot. 11: 260, 1902. Dryopteris fuscipes var. diplazioides (Christ) Ching ex L. K. Ling et al., Fl. Fujianica 1: 199, 1982. Type. China. Kouy-tcheou, "Mont. du Collège à Kouy-yang", 18 May 1898, Bodinier 2204 (holotype E! [E00414441]).

Dryopteris integripinnula Ching, Wuyi Sci. J. 1(1): 7, 1981. Type. China. Fujian: Taining, 21 Jun 1978, K. L. Tsai 621 (holotype, PE! [PE00044576]).

Dryopteris mimetica Ching \& C. F. Zhang, Bull. Bot. Res., Harbin 3(3): 21, 1983. Type. China. Zhejiang: Ling'an Xian, Daming Shan, 25 Jun 1981, C. F. Zhang 6733 (holotype, PE! [PE01863875]).

\section{국명: 애기지네고사리}

식물체는 상록성이다. 엽병은 길이 $10-30 \mathrm{~cm}$ 이고 담황색
이며, 전체에 인편이 다소 빽빽이 붙는다. 엽병의 인편은 선 상 피침형 또는 좁은 피침형이며, 길이 $0.8-1 \mathrm{~cm}$, 폭 $1 \mathrm{~mm}$ 이 고, 흑갈색이며, 전연이다. 엽신은 피침형으로 기부에서 가 장 넓고 길이 20-40 cm, 폭 8-18 cm이며, 1회 우상복엽이고, 점첨두이며, 딱딱한 지질이다. 중축은 인편이 다소 빽빽이 붙는다. 중축의 인편은 좁은 피침형이고, 흑갈색이며, 전연 이다. 우편은 10-15쌍으로 피침형 또는 다소 낫 모양이고, 길이 6-10 cm, 폭 1-2 cm이며, 점첨두이고, 중열 내지 심열하 며, 우편의 자루는 길이 약 $2 \mathrm{~mm}$ 정도이다. 최종열편은 10 15 쌍이고, 원두 또는 둔두이며, 거의 전연이다. 최종열편의 측맥은 단순하거나 1 회 차상으로 분지한다. 포자낭군은 중 륵 근처에 달린다. 포막은 직경 약 $1 \mathrm{~mm}$ 이고, 전연이다.

\section{분포: 일본, 중국, 한국}

한반도 분포: 전남. 낮은 산지의 숲 속

분류학적 고찰: 본 변종은 일본 및 중국의 산림층 또는 저지의 숲 가장자리에 주로 분포하며 (Nakaike, 1992; Zhang et al., 2013), 우리나라의 경우 전남 광주시 월각산에 소수의 개체가 분포하는 것이 확인되었다(Kim et al., 2004). 한편, D. decipiens var. decipiens (공작지네고사리)는 일본, 중국, 대만에 주로 분포하며 (Iwatsuki, 1995; Chang et al., 2003; Zhang et al., 2013), 우편이 전연 내지 천열하는 특 징에 의해 애기지네고사리와 구분된다. 최근 공작지네고 사리가 전남 장흥군에 분포하는 것으로 보고된 바 있으나 (Sun et al., 2012), 본 연구에서는 그 확증표본[H. D. Son et al. 115441, $116059(\mathrm{CNU})]$ 을 확인하지 못하였으며, 이에 대한 추후 확인이 요구된다.

2) Dryopteris championii (Benth.) C. Chr. ex Ching, Sin. Contr. 3: 327, 1931. Aspidium championii Benth., Fl. Hongk. 456, 1861. Type. China. Hongkong: without specific locality and date, Champion 297 (syntype K! [K001080820]); without specific locality and date, Urquhart s.n. (syntype [not seen]).

Dryopteris pseudoerythrosora Kodama in Matsum., Icon. Pl. Koisik. 1: 165, 1913. Type. Japan. Awa: Nishu, Yamasirotanimura, 22 Jul 1888, M. Miyoshi s.n. (lectotype [not seen], designated by Itô, Bot. Mag. (Tokyo) 50: 72, 1936).

Dryopteris erythrosora var. cavaleriei Rosenst., Repert. Spec. Nov. Regni Veg. 13: 131, 1914. Type. China. Guizhou: Guiyang, Nov 1912, P. Cavalerie 3771 (isotypes, GH!, NY!).

Dryopteris changii Ching, Wuyi Sci. J. 1(1): 7, 1981. Type. China. Fujian: Chong' an Xian, 19 Aug 1979, Wuyi Exped. 131 (holotype, PE! [PE00044565]).

Dryopteris bullatipaleacea Ching, Bull. Bot. Res., Harbin 2(2): 65, 1982. Type. China. Zhejiang: Shui-chang Xian, in silvis, elevation 1000 m, 7 Oct 1980, K. W. Yao 5848 (holotype, PE! [PE01863894]).

Dryopteris infrahirtella Ching \& Z. Y. Liu, Bull. Bot. Res., 
Harbin 3(4): 22, 1983. Type. China. Sichuan: Nanchuan, Jinfoshan, $1100 \mathrm{~m}$, in sylvis, 13 Aug 1982, Z. Y. Liu et al. 3534 (holotype, PE! [PE00133883]).

Dryopteris neofuscipes Ching \& Z. Y. Liu, Bull. Bot. Res., Harbin 4(3): 22, 1984. Type. China. Sichuan: Nanchuan, Jinfoshan, under mixed forest, elevation 1100 m, 27 Mar 1983, Z. Y. Liu 3945 (holotype, PE! [PE01895919]).

\section{국명: 제주지네고사리}

식물체는 상록성이다. 엽병은 길이 $25-50 \mathrm{~cm}$ 이고, 전체 에 인편이 빽빽이 붙으며, 숙존한다. 엽병 기부의 인편은 난상 피침형 또는 좁은 피침형이며, 길이 $1.5-2.5 \mathrm{~cm}$, 폭 2.5-4 mm이고, 적갈색이며, 윤기가 있고, 연한 막질이며, 가장자리에는 불규칙한 거치가 있다. 엽신은 장타원형 또 는 장타원상 난형으로 기부 또는 기부 근처에서 가장 넓 고, 길이 35-65 cm, 폭 $21-35 \mathrm{~cm}$ 이며, 2회 우상복엽이고, 점첨두이며, 짙은 녹색으로 두꺼운 지질이고, 상면에 윤 기가 있다. 중축은 인편이 빽빽이 붙는다. 중축의 인편은 넓은 피침형 또는 난상 피침형이고, 적갈색 내지 암갈색 이며, 가장자리에는 불규칙한 거치가 있다. 우편은 7-12 쌍으로 선상 피침형 또는 장타원상 피침형이고, 길이 $10-$ $28 \mathrm{~cm}$, 폭 3-10 cm이며, 점첨두이고, 뒷면에 기부가 편평 하거나 또는 주머니처럼 부푼 인편이 성글게 붙으며, 우 편의 자루는 길이 3-8 mm이다. 소우편은 12-20쌍으로 난 상 피침형 또는 피침형이고, 길이 $1.5-6 \mathrm{~cm}$, 폭 $0.8-1.8 \mathrm{~cm}$ 이며, 앞면에 배수조직이 없고, 원두 또는 둔두이며, 천열 내지 심열하고, 자루는 거의 없거나 길이 $2.5 \mathrm{~mm}$ 에 달하 며, 기부우편의 기부외측 기부소우편은 인접한 소우편보 다 작다. 소우축은 기부가 부푼 주머니 모양의 인편이 있 다. 최종열편은 타원상 피침형이고, 길이 $0.7-1 \mathrm{~cm}$, 폭 4$6 \mathrm{~mm}$ 이며, 가장자리는 치상거치를 가진다. 최종열편의 측맥은 1-5회 차상으로 분지하며, 가장자리에 닿는다. 포 자낭군은 중륵과 가장자리의 중간 또는 보다 가장자리에 치우쳐 붙는다. 포막은 직경 약 $1 \mathrm{~mm}$ 이고, 전연이다.

분포: 대만, 일본, 중국 남부, 한국

한반도 분포: 전남, 경남, 제주. 낮은 산지의 습한 숲 속 분류학적 고찰: 본 종은 대만, 일본 및 중국에 분포하며 (Iwatsuki, 1995; Chang et al., 2007; Zhang et al., 2013), 한반 도에는 제주를 포함한 남부 지역의 낮은 산지에 분포한다. 본 종은 엽신이 2회 우상복엽이며, 피침형으로 가장자리 에 불규칙한 거치가 있는 인편이 중축에 빽빽하게 붙으며, 포자낭군이 최종열편의 중륵과 가장자리의 중간 또는 가 장자리에 치우쳐 붙는 특징에 의해 본 아속내 나머지 한 반도산 분류군과 구분된다(Figs. 1B, 3B; Table 1). 한편, Lee et al. (2013)은 일본 및 중국에 분포하는 것으로 알려져 있 는 D. simasakii var. paleacea (H. Itô) Sa. Kurata (층층지네고
사리)가 서울, 제주도, 통영, 거제도 등에 분포하는 것을 보고한 바 있다. 그러나, 제주도에서 채집되어 $\mathrm{KB}$ 에 소장 된 확증표본(C.S. Lee \& G. H. Lee 120901, 120902, 120903) 및 $\mathrm{KYO}$ 에 소장된 본 분류군의 기준표본(Y. Simasaki s.n.) 을 비교한 결과, 제주도에서 채집된 개체는 제주지네고사 리와 유사한 것으로 판단되며 이에 대한 추후 확인이 요 구된다.

4) Dryopteris kinkiensis Koidz. ex Tagawa, Acta Phytotax. Geobot. 2: 200, 1933. Type. Japan. Yamashiro: Uji, Jubusan, 14 Aug 1928, K. Takeuchi s.n. (lectotype, KYO!, designated by Tagawa, Acta Phytotax. Geobot. 16: 181, 1956).

Dryopteris pseudoerythrosora var. tenuifrons H. Itô, J. Jap. Bot. 9: 59, 1933. D. championii var. tenuifrons (H. Itô) H. Itô in Nakai \& Honda, Nov. Fl. Jap. 4: 48, 1939. Type. Japan. Mino: "Iwato urbis Gihu", 7 Jan 1932, H. Itô s.n. (lectotype [not seen], designated by Itô, Bot. Mag. (Tokyo) 50: 72, 1936).

\section{국명: 엷은지네고사리}

식물체는 상록성이다. 엽병은 길이 $20-40 \mathrm{~cm}$ 이고, 전체 에 인편이 다소 성글게 붙는다. 엽병의 인편은 넓은 피침 형이고, 암갈색이며, 연한 막질이고, 가장자리에는 불규 칙한 거치가 있다. 엽신은 장타원형에서 장타원상 난형이 고, 길이 25-45 cm, 폭 20-30 cm이며, 2회 우상복엽이고, 점첨두이며, 두꺼운 지질이고, 상면에 윤기가 없다. 중축 은 인편이 다소 성글게 붙는다. 중축의 인편은 피침형이 고 길이 3-6 mm이며, 가장자리에는 불규칙한 거치가 있 다. 우편은 약 8쌍으로 피침형이고, 길이 $12-22 \mathrm{~cm}$, 폭 2$4 \mathrm{~cm}$ 이며, 미두이고, 우편의 자루는 길이 $2-5 \mathrm{~mm}$ 이다. 소 우편은 장타원형이고, 원두 또는 둔두이며, 앞면에 배수 조직이 없고, 전연 또는 가장자리에 둔거치가 있으며, 기 부우편의 기부외측 기부소우편은 인접한 소우편보다 작 다. 포자낭군은 중륵과 가장자리의 중간 또는 중륵에 치우 쳐 붙으며, 드물게 중륵과 가장자리의 중간 보다 가장자리 에 치우쳐 붙는다. 포막은 직경 약 $1 \mathrm{~mm}$ 이고, 전연이다.

분포: 일본, 중국 남부, 한국

한반도 분포: 전남, 제주. 낮은 산지의 습한 솦 속

분류학적 고찰: 본 종은 형태적으로 제주지네고사리와 유사하며, Itô (1939)는 본 종을 제주지네고사리의 변종 $[D$. championii var. tenuifrons (H. Itô) H. Itô]으로, Ohwi (1957) 및 Lee (1996)는 제주지네고사리의 이명으로 처리한 바 있 다. 그러나, 본 종은 엽신 상면에 윤기가 없고, 중축 인편이 암갈색으로 성글게 붙으며, 포자낭군이 최종열편의 중륵 과 가장자리의 중간 또는 중륵에 치우쳐 붙는 특징에 의 해 제주지네고사리와 뚜렷이 구분된다(Table 1). 한편, 본 종은 제주지네고사리와 엽록체 DNA 염기서열에서 차이 
가 나타나며 (Zhang et al., 2012), 따라서 본 분류군을 제주 지네고사리와 독립된 종으로 처리하는 것이 타당한 것으 로 판단된다.

5) Dryopteris fuscipes C. Chr., Index Filic., Suppl. 2: 14, 1917. D. bipinnata C. Chr. in H. Lév., Cat. Pl. Yun-Nan 102, 1916, non Copel. (1914). Nephrodium fuscipes (C. Chr.) Hand.Mazz., Symb. Sin. 6: 24. 1929, non C. B. Clarke (1880). Type. China. Yunnan: Kouytcheou, without date, J. Cavalerie s.n. (holotype [not seen]).

Dryopteris parafuscipes Ching \& Z. Y. Liu, Bull. Bot. Res., Harbin 4(3): 23, 1984. Type. China. Sichuan: Nanchuan, Jinfoshan, under broad-leaved forest, elevation $850 \mathrm{~m}, 16$ Aug 1983, Z. Y. Liu et al. 4362 (holotype, PE! [PE01895925]).

국명: 큰지네고사리

식물체는 상록성이다. 엽병은 길이 $20-40 \mathrm{~cm}$ 이고, 기부 에 비교적 인편이 빽빽이 붙지만 상부에서는 성글게 붙는 다. 엽병 기부의 인편은 선상 피침형 내지 좁은 피침형이 고, 길이 $0.8-1.7 \mathrm{~cm}$, 폭 1-2 mm이며, 적갈색이고, 다소 딱 딱한 막질이며, 전연이다. 엽신은 장타원형 내지 난형이 고, 길이 25-45 cm, 폭 20-30 cm이며, 2회 우상복엽이고, 점첨두이며, 지질이다. 중축의 인편은 선형이고 길이 3$6 \mathrm{~mm}$, 폭 $0.1 \mathrm{~mm}$ 이며, 적갈색이고, 가장자리는 전연이다. 우편은 약 8쌍으로 피침형이고, 길이 $12-22 \mathrm{~cm}$, 폭 2-4 cm 이며, 미두이고, 우편의 자루는 길이 2-5 mm이다. 소우편 은 장타원형이고, 원두 또는 둔두이며, 앞면에 배수조직 이 있고, 가장자리에 둔거치가 있거나, 드물게 천열하며, 기부우편의 기부외측 기부소우편은 인접한 소우편보다 작다. 최종열편의 측맥은 뒷면에서 불분명하다. 포자낭군 은 중륵 근처 또는 중륵과 가장자리의 중간에서 중륵에 치우쳐 붙는다. 포막은 직경 1-1.5 mm이고, 전연이다.

분포: 인도차이나 반도, 일본, 중국 남부, 한국

한반도 분포: 전남, 경남, 제주. 낮은 산지의 숲 속

분류학적 고찰: 본 종은 중국 윤난성에서 채집된 개체를 근거로 기재된 분류군으로, 인도차이나 반도, 일본 및 중 국에 주로 분포하며 (Iwatsuki, 1995; Zhang et al., 2013), 한 반도에서는 제주도를 비롯한 남부 지역에 다소 드물게 확 인된다. 본 종은 엽신 및 인편의 형태에 있어 홍지네고사 리와 유사하나, 엽병 인편이 적갈색이며, 소우편이 원두 또는 둔두이고, 최종열편의 측맥이 뒷면에서 불분명하며, 포자낭군이 주로 중륵 근처에 붙는 특징으로 홍지네고사 리와 구분된다(Table 1).

6) Dryopteris erythrosora (D. C. Eaton) Kuntze, Revis. Gen. Pl. 2: 812, 1891. Aspidium erythrosorum D. C. Eaton in Perry,
Narr. Exped. China Japan 2: 232, 330, 1857. Lastrea erythrosora (D. C. Eaton) T. Moore, Index Fil. 91, 1858. Nephrodium erythrosorum (D. C. Eaton) Hook., Sp. Fil. 4: 120, 1862. A. filix-mas var. erythrosorum (D. C. Eaton) Christ, Farnkr. Erde 257, 1897. N. filix-mas var. erythrosorum (D. C. Eaton) Matsum., Index Pl. Jap. 1: 319, 1904. Type. Japan. Shimoda, 1853-1856, C. Wright s.n. (syntype, GH! [GH00021 482], K! [K001080803, K001080804]); without date, S. W. Williams \& J. Morrow s.n. (syntype, GH! [GH00112150]).

Aspidium cystolepidotum Miq., Ann. Mus. Bot. Lugd.-Bat. 3: 177, 1867. D. cystolepidota (Miq.) C. Chr., Index Filic. 260, 1905. D. erythrosora var. cystolepidota (Miq.) Makino, Bot. Mag. (Tokyo) 23: 144, 1909. Type. Japan. without specific locality and date, Buerger s.n. (lectotype, L! [908.342-120], designated by Ohba et al., Bull. Univ. Mus. Univ. Tokyo 41: 23, 2005); Siebold s.n. (syntype, L! [908.342-124]).

Dryopteris taquetii Christ, Repert. Spec. Nov. Regni Veg. 5: 284, 1908. Type. Korea. Quelpaert: without specific locality, Aug 1907, U. Faurie 2200 (syntype, KYO! [KYO00077528], E!); "in lacunis Moktjong”, Oct 1907, Taquet 66 (syntype, KYO! [KYO00077527], E!).

Dryopteris takesimensis Kodama ex Nakai, Rep. Veg. Ooryongto 14 \& 33, 1919. Type. Korea. Gyeongsangbuk-do: Isl. Ulleung, without specific date and collector (holotype [not seen]).

Dryopteris bulligera Ching, Bull. Fan Mem. Inst. Biol. 8: 483, 1938. Type. China. Sichuan: Haochuan Xian, Hsien, without date, T. F. Lu 47 (holotype [not seen]).

Dryopteris pseudoerythrosora Ching \& C. F. Zhang, Bull. Bot. Res., Harbin 3(3): 27, 1983, non Kodama (1913). Type. China. Zhejiang: Hangzhou, Qinglung Shan, elevation $10 \mathrm{~m}$., in sylvis, 27 Apr 1982, C. F. Zhang 7235 (holotype, PE! [PE01895926]).

\section{국명: 홍지네고사리}

식물체는 상록성이다. 엽병은 길이 20-40 cm이고, 기부 에 비교적 인편이 빽빽이 붙지만 상부에서는 성글게 붙는 다. 엽병 기부의 인편은 선상 피침형 내지 좁은 피침형이 고, 길이 $0.8-1.5 \mathrm{~cm}$, 폭 $1.3-2 \mathrm{~mm}$ 이며, 갈색 또는 흑갈색이 고, 다소 딱딱한 막질이며, 전연이다. 엽신은 장타원형에 서 장타원상 난형으로 상부를 향하여 점진적 또는 갑자기 좁아지고, 길이 $30-50 \mathrm{~cm}$, 폭 20-40 cm이며, 2회 우상복엽 이고, 점첨두이며, 지질이다. 중축의 인편은 선형이고 길 이 4-6 mm, 폭 $0.1 \mathrm{~mm}$ 이며, 흑갈색이고, 전연이다. 우편은 약 10 쌍으로 장타원형 내지 피침형이고, 길이 $12-25 \mathrm{~cm}$, 폭 2-5 cm이며, 미두이고, 우편의 자루는 길이 $2-5 \mathrm{~mm}$ 이 다. 소우편은 장타원형 내지 피침형이고, 앞면에 배수조 직이 있으며, 예두 또는 둔두, 드물게 원두이고, 가장자리 
는 둔거치가 있거나 천열하며, 기부우편의 기부외측 기부 소우편은 인접한 소우편보다 작다. 최종열편의 측맥은 13 회 차상으로 분지하며, 소우편의 뒷면의 맥은 명확하다. 포자낭군은 중륵과 가장자리의 중간 또는 보다 중륵에 치 우쳐 붙는다. 포막은 직경 $1.0-1.5 \mathrm{~mm}$ 이고, 전연이다.

\section{분포: 일본, 중국 남부, 한국}

한반도 분포: 충남, 경북, 경남, 전북, 전남, 제주. 저지대 숲 속. 남부의 상록수림에 흔함

분류학적 고찰: 본 종은 일본에서 채집된 개체를 근거로 Koidzumi (1932)에 의해 기재된 D. nipponensis Koidz.(참지 네고사리)와 형태적으로 유사하며, Park (1975), Lee (1980) 및 Lee (2006)는 참지네고사리가 한반도 남부, 제주도 및 울릉도에 분포하는 것으로 보고하였다. 그러나, Iwatsuki (1995)는 D. nipponensis를 일본 특산으로 보고하였으며, 본 연구에서 $\mathrm{KYO}$ 에 소장되어 있는 D. nipponensis의 기준 표본(K. Takeuchi s.n.)을 확인한 결과, 한반도에서 채집되 어 참지네고사리로 동정된 표본은 홍지네고사리의 오동 정인 것으로 판단된다. 참지네고사리는 엽신이 넓은 난형 으로 상부에서 갑자기 좁아지며, 소우편이 장타원상 난형 내지 난형으로 천열 내지 심열하는 특징에 의해 홍지네고 사리와 구분된다(Itô, 1939; Iwatsuki, 1995). 한편, Lee (2006)는 D. caudipinna (가는홍지네고사리), D. hondoensis Koidz. (큰홍지네고사리) 및 D. hondoensis f. rubisora Sa. Kurata (새큰홍지네고사리)가 우리나라에 분포하는 것으 로 보고하였으나, 이들의 확증표본을 확인하지 못하여 분 류학적 처리를 보류하였다.

7) Dryopteris amurensis Christ, Bull. Acad. Int. Géogr. Bot. 20(Mém.): 164, 1909. Type. Japan. Sakalin: Takuiosawa, 24 Jul 1908, U. Faurie 302 (syntype, KYO!, E! [E00414403]); Russia. "Sophiisk, in ripa sinistra fluminis Amur, in declivibus montium ad truncos putridos", 24 Aug 1871, Augustinoff s.n. (syntype [not seen]).

\section{국명: 아물고사리}

식물체는 낙엽성이다. 엽병은 길이 $20-40 \mathrm{~cm}$ 이고 담황 색이며, 전체에 인편이 성글게 붙지만 성숙하면 탈락한다. 엽병의 인편은 난형 또는 넓은 난형이고, 길이 $4-9 \mathrm{~mm}$, 폭 2-4 mm이며, 담갈색이고, 전연이다. 엽신은 오각형이고, 길이 $18-25 \mathrm{~cm}$, 폭 $20-26 \mathrm{~cm}$ 이며, 3-4회 우상복엽이고, 예 두이고, 얇은 초질이다. 중축은 인편이 성글게 붙거나 또 는 거의 없다. 중축의 인편은 좁은 피침형이고, 담갈색이 다. 우편은 5-7쌍으로 기부우편은 넓은 삼각상 피침형이 고, 다른 나머지 우편은 좁은 피침형 또는 선상 피침형이 며, 길이 $10-15 \mathrm{~cm}$, 폭 $8-12 \mathrm{~cm}$ 이고, 뒷면에 인편이 거의 없으며, 예두이고, 우편의 자루는 길이 $0.8-1.2 \mathrm{~cm}$ 이다. 소
우편은 5-8쌍으로 좁은 피침형 또는 선상 피침형이고, 길 이 8-10 cm, 폭 3-4.5 cm이며, 예두이고 기부우편의 기부 외축 기부소우편이 인접한 소우편보다 크고, 소우편의 자 루는 길이 3-5 mm이다. 제 2 차 소우편은 장타원형 또는 타 원상 피침형이고, 예두 또는 둔두이며, 가장자리는 심열 하거나 전열하고, 자루는 거의 없다. 최종열편은 장타원 형이며, 길이 $7 \mathrm{~mm}$, 폭 $4 \mathrm{~mm}$ 정도이고, 원두 또는 둔두이 며, 가장자리는 끝이 바늘모양인 치상거치이다. 최종열편 의 측맥은 단순하지만 드물게 1 회 차상으로 분지하며, 가 장자리에 닿는다. 포자낭군은 중륵과 가장자리의 중간 또 는 보다 가장자리에 치우쳐 붙는다. 포막은 직경 약 $0.7 \mathrm{~mm}$ 이고, 거의 전연이다.

분포: 러시아 동부, 일본, 내몽골을 포함한 중국 북동부, 한국

한반도 분포: 북부 지방

분류학적 고찰: 본 종은 러시아, 일본 및 중국에 주로 분 포하며 (Iwatsuki, 1995; Zhang et al., 2013), 우리나라의 경 우 북부 지방에 생육하는 것으로 알려져 있다(Park, 1975; Lee 2006; Kim et al., 2007). 본 종은 관중속내 유연관계에 있어 학자간 견해 차이가 심하다(Itô, 1939; Fraser-Jenkins, 1986; Zhang et al., 2012; Zhang et al., 2013). Itô (1939) 및 Franser-Jenkins (1986)는 넓은 난형의 엽병 인편을 가지는 특징에 의해 본 종을 관중아속 Lophodium절[sect. Lophodium (Newman) C. Chr.]에 속하는 분류군으로 처리하였으며, Zhang et al. (2012)은 엽록체 DNA 염기서열 분석을 통해 이를 지지한 바 있다. 그러나, 본 종의 소우축에는 홍지네 족제비고사리아속 분류군들의 특징인 기부가 주머니 모 양으로 부푼 인편이 달리며, Zhang et al. (2013)은 본 종을 홍지네족제비고사리아속으로 처리한 바 있다.

8) Dryopteris formosana (Christ) C. Chr., Index Filic. 266, 1905. Aspidium formosanum Christ, Bull. Herb. Boissier, ser. 2, 4: 615, 1904. Type. Taiwan. "Taitum, Hokuto in lacunis", May 1903, Faurie 687 (holotype, P! [P00630715]).

Polystichum constantissimum Hayata, Icon. Pl. Formosan. 4: 191, 1914. Type. Taiwan. Taityu: Arisan, Jan 1912, B. Hayata \& S. Sasaki s.n. (isotype, KYO!).

Polystichum varium var. eurylepidotum Rosenst., Hedwigia 56: 340, 1915. D. varia var. eurylepidota (Rosenst.) H. Itô, Bot. Mag. (Tokyo) 50: 127, 1936. Type. Taiwan. Taityu: Bunkikiyo, elevation 2000 m, May 1914, U. Faurie 384 (isotype, KYO!).

Dryopteris takeuchiana Koidz., Acta Phytotax. Geobot. 1: 30, 1932. D. bissetiana var. takeuchiana (Koidz.) H. Itô, Bot. Mag. (Tokyo) 50: 36, 1936. Type. Japan. Yamasiro: Uji, Mimurodo, 23 Jun 1931, K. Takeuchi s.n. (lectotype, KYO!, designated by Tagawa, Acta Phytotax. Geobot. 16: 184, 1959; 
isolectotype, $\mathrm{KYO}$ !).

국명: 홍노족제비고사리

식물체는 상록성이다. 엽병은 길이 $12-40 \mathrm{~cm}$ 이고, 담황 색이며, 기부에 인편이 다소 빽빽이 붙지만 상부에는 다 소 성글게 붙는다. 엽병의 인편은 좁은 피침형이며, 길이 $0.5-1.5 \mathrm{~cm}$, 폭 $1-2.5 \mathrm{~mm}$ 이고, 흑갈색이며, 윤기가 있고, 전 연이다. 엽신은 오각형이고, 길이 $15-35 \mathrm{~cm}$, 폭 $15-30 \mathrm{~cm}$ 이며, 상부를 향하여 다소 갑자기 좁아지고, 3 회 혹은 드물 게 4회 우상복엽이며, 점첨두이고, 뚜꺼운 초질 또는 지질 이다. 중축, 우축과 소우축은 기부가 주머니처럼 부푼 인 편이 빽빽이 붙는다. 중축의 인편은 선형이고, 암갈색 혹 은 흑색이다. 우편은 4-6쌍으로 기부우편은 삼각상 피침 형이고, 다른 나머지 우편은 장타원상 피침형 또는 선상 피침형이며, 길이 $11-20 \mathrm{~cm}$, 폭 9-16 cm이고, 점첨두이며, 우편의 자루는 길이 5-7 mm이다. 소우편은 5-8쌍으로 선 상 피침형 또는 장타원상 피침형이고, 길이 7-12 cm, 폭 3$7 \mathrm{~cm}$ 이며, 예두 또는 점첨두이고, 기부우편의 기부외축 기부소우편이 인접한 소우편보다 크고, 소우편의 자루는 약 $1.5 \mathrm{~mm}$ 이다. 제 2 소우편은 14-18쌍으로 타원형 또는 장 타원형이고, 길이 1-2 cm, 폭 5-8 mm이며, 원두 또는 둔두 이고, 천열하거나 중렬하고, 가장자리는 끝이 바늘모양인 치상거치이다. 최종열편의 측맥은 1-3회 차상으로 분지 하며, 가장자리에 닿는다. 포자낭군은 중륵과 가장자리의 중간 또는 가장자리에 치우쳐 붙는다. 포막은 직경 1$1.5 \mathrm{~mm}$ 이고, 거의 전연이다.

분포: 대만, 일본, 중국 남부, 필리핀, 한국 한반도 분포: 제주. 산지의 습한 상록수림

분류학적 고찰: 본 종은 대만, 일본, 중국 남부, 필리핀에 주로 분포하며 (Iwatsuki, 1995; Zhang et al., 2013), 우리나 라의 경우 제주도의 습한 상록수림에 생육하는 것이 확인 되었다. Lee and Park (2014)은 포자의 미세구조 관찰을 통 해, 본 종이 침상의 포자외막을 가지는 특징에 의해 관중 속내 한반도산 다른 분류군들과 뚜렷이 구분되는 것을 밝 힌 바 있다.

9) Dryopteris varia (L.) Kuntze, Revis. Gen. Pl. 2: 814, 1891. Polypodium varium L., Sp. Pl. 1090, 1753. Aspidium varium (L.) Sw., J. Bot. (Schrader) 1800(2): 35, 1801. Nephrodium varium (L.) C. Presl, Reliq. Haenk. 1: 36, 1825. Polystichum varium (L.) C. Presl, Abh. Königl. Böhm. Ges. Wiss., ser. 5, 6: 417. 1851. Lastrea varia (L.) T. Moore, Index Fil.: 107, 1858. Type. China, Gwandung: without specific locality and date, Osbeck s.n. (holotype [not seen]).

Lastrea opaca Hook., Hooker's J. Bot. Kew Gard. Misc. 9: 339, 1857. Aspidium opacum (Hook.) Benth., Fl. Hongk.: 456, 1861. Nephrodium villosum var. opacum (Hook.) Hieron., Bot.
Jahrb. Syst. 34: 446, 1904. Type. China. Guangdong: Hong Kong and mainland N. W. of Hong Kong, withdout date, J. C. Bowman s.n. (lectotype, K! [K001080901], designated by Fraser-Jenkins, Bull. Brit. Mus. (Nat. Hist.), Bot. 18: 432, 1989).

Nephrodium coriaceum C. Hope, J. Bot. 28: 328, 1890. Type. India. Assam: Kapili Hot Springs, North Cachar Hills, elevation 1000 ft, Feb 1890, G. Mann s.n. (lectotype, K! [K001080980], designated by Fraser-Jenkins, Bull. Brit. Mus. (Nat. Hist), Bot. 18: 432, 1989).

Dryopteris yabei Hayata, J. Coll. Sci. Imp. Univ. Tokyo 30: 424, 1911. Type. Taiwan. Kushaku and Shintengai, 16 Oct 1899, K. Miyake s.n. (holotype, TI [not seen]).

Polystichum hololepis Hayata, Icon. Pl. Formosan. 5: 332, 1915. Dryopteris hololepis (Hayata) Tagawa, Acta Phytotax. Geobot. 4: 133, 1935. D. yabei var. hololepis (Hayata) H. Itô, Bot. Mag. (Tokyo) 50: 128, 1936. Type. Taiwan. Taihoku: without date, Takeo Ito \& S. Fujii s.n. (isotype, TAIF!, TI [not seen]).

Dryopteris matsuzoana Koidz., Bot. Mag. (Tokyo) 39: 15, 1925. D. yabei var. matsuzoana (Koidz.) H. Itô, Bot. Mag. (Tokyo) 50: 128, 1936. Type. Japan. Iyo: Uchimimura, Minamiuwagun, 13 Oct 1923, M. Ogata s.n. (holotype, KYO!).

Dryopteris ogawae H. Itô in Nakai, Iconogr. Pl. Asiae Orient. 1: 18, t. 9, 1935. D. yabei var. ogawae (H. Itô) H. Itô, Bot. Mag. (Tokyo) 50: 128, 1936. D. yabei f. ogawae (H. Itô) H. Itô in Nakai \& Honda, Nov. Fl. Jap. 4: 59, 1939. Type. Japan. Awa: Kiyozumiyama, April 1933, M. Kishida s.n. (holotype [not seen]).

Dryopteris consimilis Ching \& P. C. Chiu, Bot. Res. Acad. Sin. 2: 25, 1987, non (Fée ex Baker) C. Chr. (1907). Type. China. Zhejian: Hangchow, without specific locality, Jul 1955, P. C. Chiu 510 (holotype, PE! [PE00133954]).

\section{국명: 족제비고사리}

상록성 식물로, 지하경은 비스듬히 선다. 엽병은 길이 30-40 cm이고, 기부에 인편이 다소 빽빽이 붙지만 상부에 서 성글게 붙는다. 엽병의 인편은 선형이며, 길이 2$2.5 \mathrm{~cm}$, 폭 $1.3-1.7 \mathrm{~mm}$ 이고, 적갈색이며, 전연이다. 엽신은 오각형이고, 상부를 향하여 갑자기 좁아지며, 길이 30$50 \mathrm{~cm}$, 폭 20-40 cm이고, 2회 우상복엽, 드물게 3회 우상복 엽이고, 긴 점첨두이며, 앞면은 담녹색이고, 얇은 혁질이 다. 중축의 인편은 선형이고, 길이 4-6 mm, 폭 $0.1 \mathrm{~mm}$ 내 외이며, 적갈색, 드물게 흑갈색이고, 가장자리는 기부에 불규칙한 거치가 있지만 위쪽에서는 거의 전연이다. 기부 우편을 제외한 우편은 9-13쌍으로 선형 내지 피침형이며, 길이 $10-20 \mathrm{~cm}$, 폭 $2-5 \mathrm{~cm}$ 이고, 뒷면에 인편이 성글게 붙 으며, 미두이고, 우편의 자루는 길이 2-8 mm이다. 기부우 
편은 길이 $15-25 \mathrm{~cm}$ 이며, 중축과 우축의 각도는 $40-50^{\circ}$ 이 고, 미두이며, 자루는 길이 $0.7-1.2 \mathrm{~cm}$ 이다. 소우편(기부우 편의 기부외측 기부소우편 제외)은 난형 내지 피침형이고, 뒷면에 기부가 주머니처럼 부푼 작은 인편이 성글게 붙으 며, 예두이고, 기부우편의 기부외측 기부소우편은 좁은 피침형 내지 선형이고, 인접한 소우편보다 크며, 길이 8$12 \mathrm{~cm}$, 폭 $1.5-3 \mathrm{~cm}$ 이다. 최종열편은 난형이고, 예두이며, 가장자리는 치상거치이나 바늘모양이 아니다. 최종열편 의 측맥은 $1-3$ 회 차상으로 분지한다. 포자낭군은 중륵과 가장자리의 중간 내지 보다 가장자리에 치우쳐 붙는다. 포막은 직경 $0.7-1 \mathrm{~mm}$ 이고, 거의 전연이다.

분포: 대만, 인도, 인도차이나 반도, 일본, 중국 남동부 및 중남부, 태국, 필리핀, 한국

한반도 분포: 제주 남부. 개울가 습한 곳 혹은 낮은 산지 의 습한 숲 속. 드물게 생육

분류학적 고찰: 본 종은 아시아 지역에 넓게 분포하나 (Fraser-Jenkins, 1989; Iwatsuki, 1995; Zhang et al., 2013), 우 리나라의 경우 제주도 남부에 소수의 개체가 생육한다. Lee et al. (2006)은 족제비고사리, 큰족제비고사리, 애기족 제비고사리, 산족제비고사리, 바위족제비고사리 및 광릉 족제비고사리 등 형태적으로 유사한 한반도산 D. varia complex의 주요 식별형질에 대한 수리분류학적 연구를 통 해, 본 종은 엽신 상부가 급격히 좁아지고, 기부우편이 잎 선단부를 향해 급하게 휘어지는 특징에 의해 한반도산 $D$. varia complex에 속하는 나머지 분류군과 구분되는 것을 밝힌 바 있다(Fig. $1 \mathrm{H})$. 한편, 본 종의 한반도산 개체들은 무배생식형의 삼배체이며 (Lee et al., 2006), 족제비고사리 의 이배체 유성생식형 개체와 이배체 무성생식형 개체 간 의 교잡에 의해 유래된 동질배수체로 추정된다(Lee and Park, 2013). 최근, Hori et al. (2014)는 족제비고사리의 일본 산 무배생식형 삼배체 개체들도 동질배수체임을 확인한 바 있다. 본 종의 유성생식형 이배체 개체는 대만에서 보 고되었으며 (Ebihara et al., 2014), 무배생식형의 이배체 개 체들은 일본에 생육하고 있다(Hirabayashi, 1974).

10) Dryopteris pudouensis Ching, Bull. Bot. Res., Harbin 3(3): 11, 1983. Type. China. Zhejiang: Pudou Island, elevation $40 \mathrm{~m}$, in silvis, 30 Oct 1979, K. Y. Shing et al. 306 (holotype, PE! [PE01895929], isotype, PE! [PE00044583]).

Polystichum pacificum Nakai, Bot. Mag. (Tokyo) 39: 119, 1925. D. pacifica (Nakai) Tagawa, Coll. Ill. Jap. Pterid. 100, 211, 1959, non Christ (1912). Type. Japan. Aki: Miyajima, Nov 1913, Faurie 444 (syntype, KYO!); Ikegami, A. Kimura s.n. (syntype [not seen]); Sagami: Isl. Yenoshima, T. Nakai s.n. (syntype [not seen]).

Polystichum hololepis var. hikonense H. Itô, J. Jap. Bot. 10: 451, 1934. D. bissetiana var. hikonensis (H. Itô) H. Itô, Bot.
Mag. (Tokyo) 50: 36, 1936. D. varia var. hikonensis (H. Itô) Sa. Kurata in Nameg. \& Sa. Kurata, Enum. Jap. Pterid.: 304, 341, 1961. D. varia subsp. hikonensis (H. Itô) Sugim., Keys Herb. Pl. Jap. Pterid. 281, 404, 1966. Dryopteris hikonensis (H. Itô) Nakaike, New Fl. Jap. Pterid., Revised \& Enlarged ed., 841, 1992. Type. Japan. Oomi: Hikone, Siroyama, 15 Jan 1933, H. Itô 46 (holotype [not seen]).

Dryopteris lungjingensis Ching \& P. C. Chiu, Bot. Res. Acad. Sin. 2: 27, 1987. Type. China. Zhejiang: Hang Chow, Lung-jing, P. C. Chiu 3477 (holotype, PE! [PE01863776]).

Dryopteris yushanensis Ching \& P. C. Chiu, Bot. Res. Acad. Sin. 2: 28, 1987. Type. China, Zhejiang: Fu-yang, Yu-shan, 9 Sep 1973, P. C. Chiu 4486 (holotype, PE! [PE01863777]).

Dryopteris quadrifida Ching ex K. H. Shing \& J. F. Cheng, Jiangxi Sci. 8(3): 49, 1990. Type. China. Jiangxi: Wugongshan, Guanyinyan, 9 Sep 1954, Jiangxi Exped. 1161 (holotype, PE![PE01863701].

\section{국명: 큰족제비고사리}

식물체는 상록성이다. 엽병은 길이 $20-30 \mathrm{~cm}$ 이고, 전체 에 인편이 빽빽이 붙는다. 엽병의 인편은 선형이며, 길이 $1-1.5 \mathrm{~cm}$, 폭 $0.7-1.2 \mathrm{~mm}$ 이고, 흑갈색 또는 흑색이며, 전연 이다. 엽신은 난형이고, 상부를 향하여 다소 갑자기 좁아 지며, 길이 25-40 cm, 폭 25-30 cm이고, 2-3회 우상복엽이 며, 긴 점첨두이고, 앞면은 녹색이며, 두꺼운 혁질이다. 중 축의 인편은 선형이고, 길이 $3.5-5 \mathrm{~mm}$, 폭 $0.12 \mathrm{~mm}$ 내외이 며, 흑갈색 또는 흑색이고, 전연이거나 또는 매우 드물게 불규칙한 거치가 있다. 기부우편을 제외한 우편은 8-14쌍 으로 선형 내지 피침형이고, 길이 $10-15 \mathrm{~cm}$, 폭 $3-5 \mathrm{~cm}$ 이 며, 미두이고, 우편의 자루는 길이 2-8 mm이다. 기부우편 은 길이 $15-20 \mathrm{~cm}$ 이며, 중축과 우축의 각도는 $55-70^{\circ}$ 이고, 미두이며, 자루는 길이 $0.7-1.2 \mathrm{~cm}$ 이다. 소우편은 난형 내 지 피침형이고, 뒷면에 기부가 주머니처럼 부푼 작은 인 편이 성글게 붙으며, 예두이고, 기부우편의 기부외측 기 부소우편은 인접한 소우편보다 크며, 길이 6-8 cm, 폭 2$3 \mathrm{~cm}$ 이다. 최종열편은 난형이고, 예두이며, 가장자리는 치상거치이나 바늘모양이 아니다. 최종열편의 측맥은 13 회 차상으로 분지한다. 포자낭군은 중륵과 가장자리의 중간 내지 보다 가장자리에 치우쳐 붙는다. 포막은 직경 $1-1.3 \mathrm{~mm}$ 이고, 거의 전연이다.

\section{분포: 일본, 중국 남부, 한국}

한반도 분포: 경남, 전남, 제주. 저지대 솦 속의 그늘진 곳 분류학적 고찰: 본 종은 원래 $\operatorname{Nakai(1925)ㅇㅔ~ㅇㅢㅎㅐ~ㅇㅣㄹㅂㅗㄴㅇㅔ~}$ 서 채집된 개체를 근거로 Polystichum pacificum Nakai로 개 재되었던 분류군으로, Nakai(1925)는 본 분류군이 족제비 고사리와 유사하나, 인편이 흑색이고 포막이 보다 작고 
붉게 변하지 않는 특징에 의해 구분되는 것으로 기술하였 다. 한편 Tagawa(1959)는 Polystichum pacificum를 관중속으 로 전이하였으며, 이후 최근까지 많은 학자들은 본 종의 정명으로 D. pacifica (Nakai) Tagawa를 사용하여 왔다 (Park, 1975; Fraser-Jenkis, 1986; Lee, 1980; Iwatsuki, 1995; Lee 2006; Lee et al., 2006; Kim et al., 2007; Lee and Park, 2013, 2014; Zhang et al., 2013). 그러나, 본 종의 정명으로 사 용되어 왔던 D. pacifica (Nakai) Tagawa는 사모아에서 채집 된 개체(B. P. G. Hochreutiner 3226)에 근거하여 Christ(1912) 에 의해 기재된 D. pacifica Christ의 후일동음명(later homonym)으로 비합법명인 것으로 밝혀졌다.

한편, Zhang et al. (2013)은 일본에서 기재된 P. hololepis var. hikonense H. Itô (Itô, 1934) $[=D$. hikonensis (H. Itô) Nakaike]와 중국에서 기재된 D. pudouensis Ching (Ching and Zhang, 1983), D. lungjingensis Ching \& P. C. Chiu, D. yushanensis Ching \& P. C. Chiu (Ching and Chiu, 1987) 및 D. quadrifida Ching ex K. H. Shing \& J. F. Cheng (Shing and Cheng, 1990)을 모두 본 종과 동일한 분류군으로 처리한 바 있으며, 본 연구에서 이들 분류군들의 원기재문 및 기 준표본을 검토한 결과 상기 분류군들은 Zhang et al. (2013) 의 견해대로 모두 본 종과 동일한 것으로 확인되었다. 따 라서, 본 종(큰족제비고사리)을 관중속의 종으로 인식할 경우, 그 정명은 비합법명인 D. pacifica (Nakai) Tagawa를 제외하고 종 수준에서 선취권을 갖는 D. podouensis Ching 이 된다.

큰족제비고사리(D. podouensis)는 족제비고사리(D. varia) 또는 산족제비고사리(D. bissetiana)와 형태적으로 유사하 여, 일부 학자들은 큰족제비고사리를 족제비고사리의 이 명 (Ohba, 1971) 또는 변종 (Nakaike, 1975; Lee, 1996)으로 인 식하거나, 산족제비고사리의 변종(Itô, 1939)으로 처리한 바 있다. Lee et al. (2006)은 본 종이 형태적으로 족제비고사 리와 유사하나, 엽신이 난형이며, 기부우편의 기부외측 기 부소우편이 난형 내지 피침형이고, 엽병 인편이 흑색인 특 징에 의해 족제비고사리와 뚜렷이 구분되는 것을 밝힌 바 있다(Fig. 1I; Table 1). 또한, 본 종은 엽록체 DNA 계통수 상 에서 족제비고사리와 함께 하나의 단계통군을 형성하면 서 나머지 한반도산 관중속 분류군과 뚜렷이 구분되었으 며, 핵 DNA 염기서열에 있어 족제비고사리와 뚜렷한 차이 가 존재하였다(Lee and Park, 2013). 따라서 외부 형태 및 $\mathrm{DNA}$ 염기서열의 차이에 근거하여 큰족제비고사리를 독 립된 종으로 처리하는 것이 타당한 것으로 판단된다. 한편, 본 종의 한반도산 개체들은 무배생식형의 삼배체로 보고 되었다(Lee et al., 2006). Lee and Park (2013)은 핵 및 엽록체 DNA 염기서열 분석을 통해 본 종의 한반도산 삼배체 무배 생식형 개체는 큰족제비고사리의 유성생식형 이배체 개 체와 애기족제비고사리의 무배생식형 이배체 개체 간의 교잡에 의해 형성된 이질배수체인 것으로 추정한 바 있다.
11) Dryopteris sacrosancta Koidz., Bot. Mag. (Tokyo) 38: 108, 1924. Polystichum sacrosanctum (Koidz.) Koidz., Bot. Mag. (Tokyo) 43: 388, 1929. P. bissetianum var. sacrosanctum (Koidz.) Nakai, Bot. Mag. (Tokyo) 45: 103. 1931. D. bissetiana var. sacrosancta (Koidz.) H. Itô, Bot. Mag. (Tokyo) 50: 36, 1936. D. varia var. sacrosancta (Koidz.) Ohwi, Fl. Jap. Pterid. 88, 1957. D. varia subsp. sacrosancta (Koidz.) Sugim., Keys Herb. Pl. Jap. Pterid. 281, 405, 1966. Type. Japan. Aki: Miyajima, Nov 1913, U. Faurie s.n. (lectotype, KYO!, designated by Tagawa, Acta Phytotax. Geobot. 16: 183, 1956).

\section{국명: 애기족제비고사리}

식물체는 상록성이다. 엽병은 길이 $10-30 \mathrm{~cm}$ 이고, 전체 에 인편이 빽빽이 붙는다. 엽병의 인편은 피침형이며, 길 이 0.8-1.1 cm, 폭 1-1.4 mm이고, 흑색 또는 흑갈색이고, 전 연 또는 드물게 가장자리에 불규칙한 거치가 있다. 엽신 은 난형이고, 상부를 향하여 점진적으로 좁아지며, 길이 20-40 cm, 폭 10-25 cm이고, 3회 우상복엽, 드물게 2회 우 상복엽이며, 점첨두이고, 앞면은 황녹색 내지 녹색이며, 두꺼운 초질 또는 지질이다. 중축의 인편은 피침형이고, 길이 $2.5-4.5 \mathrm{~mm}$, 폭 $0.25-0.45 \mathrm{~mm}$ 이며, 흑색 또는 흑갈색 이고, 기부가 편평하게 주머니처럼 부풀지 않으며, 가장 자리에는 불규칙한 거치가 있다. 우편은 9-13쌍으로 난형 내지 피침형이고, 길이 $10-15 \mathrm{~cm}$, 폭 4-6 cm이며, 뒷면에 기부가 주머니처럼 부푼 인편이 성글게 붙고, 미두이며, 우편의 자루는 길이 4-8 mm이다. 기부우편은 길이 7$17 \mathrm{~cm}$ 이며, 미두이고, 자루는 길이 $0.5-1.1 \mathrm{~cm}$ 이다. 소우편 은 난형 내지 피침형이고, 뒷면에 기부가 주머니처럼 부 푼 작은 인편이 있으며, 예두이고, 기부우편의 기부외측 기부소우편은 인접한 소우편보다 크며, 길이 $3-7.5 \mathrm{~cm}$, 폭 2-4 cm이다. 최종열편은 난형이고, 예두이며, 전연 또는 가장자리에 둔거치가 있다. 최종열편의 측맥은 1-3회 차 상으로 분지한다 포자낭군은 중륵과 가장자리의 중간 내 지 보다 중륵에 치우쳐 붙는다. 포막은 직경 0.9-1.2 mm이 고, 거의 전연이다.

\section{분포: 일본, 중국 남부, 한국.}

한반도 분포: 전도. 다소 저지대의 숲 속. 비교적 흔함

분류학적 고찰: 애기족제비고사리는 산족제비고사리 (D. bissetiana)와 형태적으로 유사하여, 일부 학자들은 애 기족제비고사리를 산족제비고사리의 변종 (Itô, 1939; Nakai, 1952)으로 인식한 바 있다. 그러나, 본 종은 기부우 편의 기부외측 기부소우편이 인접한 소우편보다 길며, 중 축의 인편이 피침형으로 기부가 평평하고, 가장자리에 불 규칙한 거치가 있는 특징에 의해 산족제비고사리 및 본 아속 내 한반도산 다른 분류군과 뚜렷이 구분된다(Lee et al., 2006; Fig. 1J; Fig. 3J; Table 1). 또한, 본 종의 한반도산 
개체들은 엽록체 DNA 계통수 상에서 나머지 한반도산 홍 지네족제비고사리아속 분류군들과 구분되면서 하나의 독립된 군을 형성하였으며 (Lee and Park, 2013), 따라서 애 기족제비고사리를 독립된 종으로 처리하는 것이 타당한 것으로 판단된다. 본 종의 한반도산 개체들은 무배생식형 의 삼배체(Lee et al., 2006)이며, 일본 및 중국산 개체들도 무배생식형의 삼배체인 것으로 보고되었다(Hirabayashi, 1974; Nakato et al., 1995).

한편, 애기족제비고사리는 관중아속에 속하는 D. chinensis (Baker) Koidz.(가는잎족제비고사리)와 엽록체 DNA $r b c \mathrm{~L}$, $t r n \mathrm{~L}-t r n \mathrm{~F}$ IGS 및 $a t p \mathrm{~F}-a t p \mathrm{H}$ IGS 구간에 있어 동일한 염기서 열을 가진다(Lee and Park, 2013). 그러나, 핵 DNA 염기서 열에 근거한 계통수 상에서 애기족제비고사리는 홍지네 족제비고사리아속에 속하는 D. varia complex 분류군들과 단계통군을 형성하면서, 가는잎족제비고사리 개체들과 뚜렷이 구분되었다(Lee and Park, 2013). 이러한 핵 및 DNA 염기서열에 근거하여, Lee and Park (2013)은 애기족제비 고사리에서 가는잎족제비고사리로 세포질 유전자교류 (cytoplasmic gene flow)가 일어난 것으로 추정하였다. 관중 아속의 가는잎족제비고사리는 엽신의 형태에 있어 애기 족제비고사리와 유사하나, 기부가 주머니 모양으로 부푼 인편이 축에 존재하지 않아 홍지네족제비고사리아속에 속하는 애기족제비고사리와 매우 뚜렷이 구분된다.

12) Dryopteris bissetiana (Baker) C. Chr., Index Filic. 254, 1905. Nephrodium bissetianum Baker, J. Bot. 15: 366, 1877. Polystichum bissetianum (Baker) Nakai, Bot. Mag. (Tokyo) 45: 102, 1931. Type. Japan. Miyanosh'ta, May (without date and year), Bissett s.n. (holotype [not seen]).

Polypodium setosum Thunb. in Murray, Syst. Veg., ed. 14: 938, 1784. Aspidium setosum (Thunb.) Sw., J. Bot. (Schrader) 1800(2): 39, 1801. Polystichum setosum (Thunb.) C. Presl, Tent. Pterid. 84, 1836. Lastrea setosa (Thunb.) T. Moore, Index Fil. 103, 1858. D. varia var. setosa (Thunb.) Ohwi, Fl. Jap. Pterid. 88, 1957. D. setosa (Thunb.) Akas., Bull. Kochi Women's Coll. 7: 27, 1959, non (Blume) Kuntze (1891), nec (Baker) Kuntze (1891). D. varia subsp. setosa (Thunb.) Sugim., Keys Herb. Pl. Jap. Pterid. 405, 1966. Type. Japan. without specific locality and date, Thunberg s.n. (holotype [not seen]).

\section{국명: 산족제비고사리}

식물체는 상록성이다. 엽병은 길이 $14-27 \mathrm{~cm}$ 이고, 전체 에 인편이 빽빽이 붙는다. 엽병의 인편은 선형이며, 길이 1.4-2 cm, 폭 0.9-1.2 mm이고, 흑색 또는 흑갈색이며, 전연 이다. 엽신은 난형 내지 피침형이고, 상부를 향하여 점진 적으로 좁아지며, 길이 $25-35 \mathrm{~cm}$, 폭 9-25 cm이고, 2 회 우 상복엽, 드물게 3회 우상복엽이며, 점첨두이고, 앞면은 녹
색이며, 두꺼운 초질 또는 지질이다. 중축의 인편은 선형 으로 곧으며 위쪽을 향하거나 비스듬하고, 길이 3$5.2 \mathrm{~mm}$, 폭 0.1-0.18 mm이며, 흑색 또는 흑갈색이고, 기부 가 주머니처럼 부풀며, 전연 또는 드물게 가장자리에 1-3 개의 불규칙한 거치가 있다. 우편은 9-15쌍으로 난형 내 지 피침형이고, 길이 6-14 cm, 폭 3-6 cm이며, 뒷면에 기부 가 주머니처럼 부푼 인편이 있고, 미두이며, 우편의 자루 는 길이 $5-9 \mathrm{~mm}$ 이다. 소우편은 난형 또는 피침형이고, 뒷 면에 기부가 주머니처럼 부푼 인편이 있으며, 예두이고, 기부우편의 기부외측 기부소우편은 인접한 소우편보다 크며, 길이 $2.5-5 \mathrm{~cm}$, 폭 $1-2 \mathrm{~cm}$ 이다. 최종열편은 난형이고, 예두이며, 전연 또는 가장자리에 둔거치가 있다. 최종열 편의 측맥은 1-3회 차상으로 분지한다. 포자낭군은 보다 중륵과 가장자리의 중간 내지 중륵에 치우쳐 붙는다. 포 막은 직경 1.2-1.8 mm이고, 전연이다.

\section{분포: 일본, 중국 남부 및 동부, 한국}

한반도 분포: 전도. 다소 저지대의 숲 속. 비교적 흔함

분류학적 고찰: 일부 학자들은 산족제비고사리를 족제 비고사리(D. varia)의 변종으로 인식한 바 있다. (Ohwi, 1957; Lee 1996). 그러나, 본 종은 엽신이 상부를 향해 점진 적으로 좁아지며, 최종열편이 전연 내지 둔거치연이고, 포자낭군이 최종열편의 중륵과 가장자리의 중간 보다 중 륵에 치우쳐 붙으며, 포막이 큰 특징에 의해 족제비고사리 와 매우 뚜렷이 구분된다(Lee et al., 2006; Fig. 1K; Table 1). 또 한, Lee et al. (2006)은 주요 식별형질에 대한 수리분류학적 연구를 통해, 본 종이 엽신의 형태, 포막 및 인편의 크기 등 에 있어 바위족제비고사리 및 광릉족제비고사리와 유사하 나, 중축의 인편이 모두 곧고 위쪽을 향하거나 비스듬하게 붙는 특징에 의해 바위족제비고사리 및 광릉족제비고사리 와 구분되는 것을 밝힌 바 있다(Fig. $3 \mathrm{~K}-\mathrm{M})$. 또한, 엽록체 $\mathrm{DNA}$ 계통수 상에서 본 종의 개체들은 나머지 한반도산 관 중속 분류군들과 구분되면서 하나의 독립된 군을 형성하 였으며 (Lee and Park, 2013), 따라서 산족제비고사리를 독립 된 종으로 처리하는 것이 타당한 것으로 판단된다.

본 종의 개체들은 주로 무배생식형의 이배체 또는 삼배 체인 것으로 알려져 있다(Hirabayashi, 1974; Nakato et al., 1995; Lee et al., 2006). 한반도의 경우, 본 종은 무배생식형 의 삼배체 개체가 흔하며, 무배생식형의 이배체 개체는 매 우 드물게 나타난다(Lee et al., 2006). 한편, Lin et al. (1995)은 동위효소 분석에 근거하여 일본산 산족제비고사리의 무 배생식형 삼배체 개체는 바위족제비고사리와 큰족제비고 사리 간의 잡종이며, 이배체 유성생식형의 바위족제비고 사리를 그 모계로 추정한 바 있다. 그러나, 한반도산 산족 제비고사리의 무배생식형 삼배체 개체는 엽록체 DNA 계 통수 상에서 바위족제비고사리의 유성생식형 이배체 개 체와 서로 다른 독립된 군을 형성하였으며 (Lee and Park, 2013), 따라서 Lin et al. (1995)의 견해와 달리 바위족제비고 
사리는 산족제비고사리의 모계가 아닌 것으로 추정된다.

13) Dryopteris saxifraga H. Itô, Bot. Mag. (Tokyo) 50: 125, 1936. D. varia subsp. saxifraga (H. Itô) Sugim., Keys Herb. Pl. Jap. Pterid. 282, 405, 1966. D. varia var. saxifraga (H. Itô) H. Ohba, Sci. Rep. Tohoku Imp. Univ., Ser. 4, Biol. 36: 111, 1971. Type. Japan. Kai \& Suruga: Huzisan, 18 Aug 1924, B. Hayata F3 (holotype [not seen]).

\section{국명: 바위족제비고사리}

식물체는 상록성이다. 엽병은 길이 $18-35 \mathrm{~cm}$ 이고, 전 체에 인편이 빽빽이 붙는다. 엽병의 인편은 선형이며, 길 이 1-1.5 cm, 폭 0.8-1.1 mm이고, 흑색 또는 흑갈색이며, 전연이다. 엽신은 난형 내지 피침형이고, 상부를 향하여 점진적으로 좁아지며, 길이 $25-50 \mathrm{~cm}$, 폭 $12-33 \mathrm{~cm}$ 이고, 2회 우상복엽, 드믈게 3회 우상복엽이며, 점첨두이고, 앞 면은 녹색이며, 두꺼운 초질 또는 지질이다. 중축의 인편 은 선형으로 아래쪽을 향하다가 궁극적으로는 위쪽을 향 하는 갈고리 모양이고, 길이 $3.3-4.8 \mathrm{~mm}$, 폭 $0.1-0.15 \mathrm{~mm}$ 이며, 흑색 또는 흑갈색이고, 기부가 주머니처럼 부풀며, 전연 또는 드물게 가장자리에 1-3개의 불규칙한 거치가 있다. 우편은 9-15쌍으로 난형 내지 피침형이고, 길이 7$15 \mathrm{~cm}$, 폭 3-6 cm이며, 뒷면에 기부가 주머니처럼 부푼 인편이 있고, 미두이며, 우편의 자루는 길이 3-9 mm이다. 소우편은 난형 내지 피침형이고, 뒷면에 기부가 주머니 처럼 부푼 작은 인편이 있으며, 예두이고, 기부우편의 기 부외측 기부소우편은 인접한 소우편보다 크며, 길이 3$7.5 \mathrm{~cm}$, 폭 $1.5-3 \mathrm{~cm}$ 이다. 최종열편은 난형이고, 예두이며, 전연이거나 가장자리에 둔거치가 있고, 드물게 가장자리 가 약간 뒤로 말린다. 최종열편의 측맥은 1-3회 차상으로 분지한다. 포자낭군은 중륵과 가장자리의 중간 내지 보 다 중륵에 치우쳐 붙는다. 포막은 직경 $1.2-1.8 \mathrm{~mm}$ 이고, 거의 전연이다.

분포: 일본, 중국 북동부, 한국

한반도 분포: 전도. 다소 저지대의 숲 속. 비교적 흔함

분류학적 고찰: 본 종은 중축 인편이 모두 선형이며 아 래쪽을 향하다가 궁극적으로는 위쪽을 향하는 갈고리 형태인 특징에 의해 나머지 한반도산 홍지네족제비고사 리아속 분류군들과 매우 뚜렷이 구분된다(Lee et al., 2006; Fig 3L). 또한, 본 종은 광릉족제비고사리와 동일한 엽록체 DNA 염기서열을 가지며, 이 두 종은 엽록체 DNA 계통수 상에서 나머지 한반도산 관중속 분류군과 구분되는 하나의 독립된 군을 형성하였다(Lee and Park, 2013). 한편, 본 종의 일본산 개체들은 유성생식형의 이 배체인 것으로 보고되었으나 (Hirabayashi, 1974; Mitui, 1975), 한반도산 개체들은 대부분 무배생식형의 삼배체 이며, 유성생식형의 이배체 개체는 매우 드물게 존재한
다(Lee et al., 2006).

14) Dryopteris saxifragivaria Nakai, J. Jap. Bot. 18: 286, 1942. D. saxifraga var. deltoidea H. Itô, Bot. Mag. (Tokyo) 50: 125, 1936. Type. Korea. Keikidô: Kôryô, 5 Sep 1930, Nakai 13276 (holotype, TI [not seen]).

Dryopteris saxifragivaria f. cristata Nakai, J. Jap. Bot. 18: 286, 1942. D. varia f. cristata (Nakai) S. Y. Oh, Res. Rev. Kyungpook Natl. Univ. 26: 201, 1978. Type. Korea. Saisyôdô (Quelpaert): without specific locality, Jun 1941, Zen-Syakukei s.n. (holotype, TI [not seen]).

\section{국명: 광릉족제비고사리}

식물체는 상록성이다. 엽병은 길이 $15-25 \mathrm{~cm}$ 이고, 전체 에 인편이 빽빽이 붙는다. 엽병의 인편은 선형이며, 길이 1-2 cm, 폭 0.8-1.2 mm이고, 흑색 또는 흑갈색이며, 전연 이다. 엽신은 난형 내지 피침형이고, 상부를 향하여 점진 적으로 좁아지며, 길이 $20-40 \mathrm{~cm}$, 폭 10-20 cm이고, 2회 우 상복엽, 드물게 3회 우상복엽이며, 점첨두이고, 앞면은 녹 색이며, 두꺼운 초질 또는 지질이다. 중축의 인편은 선형 으로 곧게 위쪽을 향하거나 비스듬하게 붙는 것과 아래쪽 을 향하다가 궁극적으로는 위쪽을 향하는 갈고리 모양의 것이 섞이고, 길이 3-5 mm, 폭 0.12-0.17 mm이며, 흑색 또 는 흑갈색이고, 기부가 주머니처럼 부풀며, 전연이 또는 드물게 가장자리에 1-3개의 불규칙한 거치가 있다. 우편 은 9-15쌍으로 난형 내지 피침형이고, 길이 5-15 cm, 폭 3$6 \mathrm{~cm}$ 이며, 뒷면에 기부가 주머니처럼 부푼 인편이 있고, 미두이며, 우편의 자루는 길이 3-9 mm이다. 소우편은 난 형 내지 피침형이고, 뒷면에 기부가 주머니처럼 부푼 작 은 인편이 있으며, 예두이고, 기부우편의 기부외측 기부 소우편은 인접한 소우편보다 크며, 길이 2-5 cm, 폭 1$2 \mathrm{~cm}$ 이다. 최종열편은 난형이고, 예두이며, 전연 또는 가 장자리에 둔거치가 있고, 드물게 가장자리가 약간 뒤로 말린다. 최종열편의 측맥은 1-3회 차상으로 분지한다. 포 자낭군은 중륵과 가장자리의 중간 내지 보다 중륵에 치우 쳐 붙는다. 포막은 직경 $1.2-1.8 \mathrm{~mm}$ 이고, 거의 전연이다.

\section{분포: 일본, 한국}

한반도 분포: 경기, 경남, 전북, 제주. 저지대 솦 속. 드물 게 생육

분류학적 고찰: Itô (1936)는 경기도에서 채집된 표본을 근거로 다소 삼각형의 엽신을 가지는 특징에 의해 $D$. saxifraga var. deltoidea를 기재하였다. 그 후, Nakai (1942)는 본 분류군을 종으로 승격하여 D. saxifragivaria라 명명하 면서, 인편의 형태에 근거하여 본 종을 바위족제비고사리 와 족제비고사리 간의 잡종인 것으로 추정하였다. 그러나, 본 종을 바위족제비와 산족제비고사리 간의 잡종(Knobloch, 1976; Lee, 1980) 또는 족제비고사리와 산족제비고사리 간 
의 잡종(Fraser-Jenkins, 1986)으로 추정하는 등 학자에 따 라 본 종의 부모종에 대해 논란이 계속되어 왔다. Lee et al. (2006)은 본 종의 한반도산 개체들이 무배생식형의 삼배 체로, 엽신의 형태, 포막 및 인편의 크기 등 주요 식별형질 에 있어 바위족제비고사리 및 산족제비고사리와 매우 유 사하나, 곧은 형태의 인편과 갈고리 형태의 인편이 중축 에 섞여 붙는 특징에 의해 본 종을 바위족제비고사리와 산족제비고사리 간의 잡종으로 추정한 바 있다. 이 후, Lee and Park (2013)은 핵 및 엽록체 DNA 분석 결과에 의거하 여, 본 종이 바위족제비고사리의 이배체 유성생식형 개체 와 산족제비고사리의 삼배체 무배생식형의 이배체 개체 간의 종간 교잡에 의해 기원된 것을 밝힌 바 있다. 한반도 의 경우 본 종은 그 부모종으로 추정되는 상기 두 분류군 의 개체들과 함께 산발적으로 분포한다.

\section{사 사}

본 연구는 환경부 “차세대에코이노베이션기술개발사 업(416-111-005)”과 국립생물자원관 “한반도 고유종 특성 평가 및 총람발간(NIBR201506101)”의 지원으로 수행된 과제임

\section{Literature Cited}

Chang, H.-M., W.-L. Chiou and J.-C. Wang. 2003. Supplements to the Pteridophytes in Taiwan (I) - Dryopteris decipiens (Hook.) Kuntze (Dryopteridaceae). Taiwania 48: 197-202.

Chang, H.-M., H.-L. Chiang, P.-F. Lu, J.-C. Wang and W.-L. Chiou. 2007. Supplements to the Pteridophytes in Taiwan (III) - Dryopteris championii (Benth.) C. Chr. ex Ching (Dryopteridaceae). Taiwania 52: 238-242.

Ching, R. C. and P. C. Chiu. 1987. Novitates Filicum Sinicarum I. Botanical Research: Contributions from the Institute of Botany, Academia Sinica 2: 1-35.

Ching, R. C. and C.-F. Zhang. 1983. New ferns of Zhejiang province. Bulletin of Botanical Research, Harbin 3(3): 1-35.

Christ, H. 1912. Plantae Hochreutineranae: Filices. Annuaire du Conservatoire et Jardin Botaniques de Genève 15-16: 178222.

Ebihara, A., N. Nakato, S. Matsumoto, Y.-S. Chao and L.-Y. Kuo. 2014. Cytotaxonomic studies on thirteen ferns of Taiwan. Bulletin of the National Museum of Nature and Science, Series B 40: 19-28.

Fraser-Jenkins, C. R. 1986. A classification of the genus Dryopteris (Pteridophyta: Dryopteridaceae). Bulletin of the British Museum (Natural History), Botany 14: 183-218.

Fraser-Jenkins, C. R. 1989. A monograph of Dryopteris (Pteridophyta: Dryopteridaceae) in the Indian subcontinent. Bulletin of the British Museum (Natural History), Botany 18: 323-477. Hirabayashi, H. 1974. Cytogeographic Studies on Dryopteris of Japan. Harashobo, Tokyo.

Hori, K., A. Tono, K. Fujimoto, J. Kato, A. Ebihara, Y. Watano and N. Murakami. 2014. Reticulate evolution in the apogamous Dryopteris varia complex (Dryopteridaceae, subg. Erythrovariae, sect. Variae) and its related sexual species in Japan. Journal of Plant Research 127: 661-684.

Itô, H. 1934. Nuntia ad filices Japonicae (II). Journal of Japanese Botany 10: 450-451.

Itô, H. 1936. Filices Japonenses. V. The Botanical Magazine 50: 125-128.

Itô, H. 1939. Polypodiaceae. Dryopteridoideae I. In Nova Flora Japonica, vol. 4. Nakai, T. and M. Honda (eds.), Saneide Co., Tokyo. Pp. 1-244.

Iwatsuki, K. 1995. Dryopteridaceae. In Flora of Japan. Pteridophyta and Gymnospermae, vol. I. Iwatsuki, K., T. Yamazaki, D. E. Boufford and H. Ohba (eds.), Kodansha, Tokyo. Pp. 120-173.

Kim, C. H., B.-Y. Sun and Y. B. Kim. 2004. Unrecorded fern species from Korean flora: Ctenitis maximowicziana, Dryopteris lunanensis and $D$. decipiens var. diplazioides (Dryopteridaceae). Korean Journal of Plant Taxonomy 34: 27-35.

Kim, C. H., B.-Y. Sun and C.-W. Park. 2007. Dryopteris. In The Genera of Vascular Plants of Korea. Flora of Korea Editorial Committee (ed.), Academy Publishing Co., Seoul. Pp. 90-98.

Knobloch, I. W. 1976. Pteridophyte hybrids. Publications of the Museum, Michigan State University, Biological Series 5: 273-352.

Koidzumi, G. 1932. Contributiones ad cognitionem florae Asiae orientalis. Acta Phytotaxonomica et Geobotanica 1: 11-30.

Kramer, K. U. 1990. Dryopteridaceae. In The Families and Genera of Vascular Plants, vol. 1. Kramer, K. U. and P. S. Green (eds.), Springer-Verlag, New York. Pp. 101-144.

Lee, C. S., K. Lee and Y. Hwang. 2013. First record of Cyrtomium laetevirens and Dryopteris simasakii var. paleacea (Dryopteridaceae) from Korea. Korean Journal of Plant Taxonomy 43: 171-180.

Lee, S.-J., Y.-D. Kim, Y. Suh, S.-K. Lee and C.-W. Park. 2006. Morphological and chromosomal variation of the Dryopteris varia (L.) Kuntze complex (Dryopteridaceae) in Korea. Plant Systematics and Evolution 262: 37-52.

Lee, S.-J. and C.-W. Park. 2013. Relationships and origins of the Dryopteris varia (L.) Kuntze species complex (Dryopteridaceae) in Korea inferred from nuclear and chloroplast DNA sequences. Biochemical Systematics and Ecology 50: 371-382.

Lee, S.-J. and C.-W. Park. 2014. Spore morphology of the genus Dryopteris Adans. (Dryopteridaceae) in Korea. Journal of 
Plant Biology 57: 302-311.

Lee, T. B. 1980. Illustrated Flora of Korea. Hyangmunsa, Seoul.

Lee, W. T. 1996. Lineamenta Florae Koreae. Academy Publishing Co., Seoul.

Lee, Y. N. 2006. New Flora of Korea. Vol. I. Kyo-Hak Publishing Co., Seoul.

Lin, S.-J., M. Kato and K. Iwatsuki. 1995. Electrophoretic variation of the apogamous Dryopteris varia group (Dryopteridaceae). Journal of Plant Research 108: 451-456.

Mitui, K. 1975. Chromosome numbers of Japanese pteridophytes. Bulletin of Nippon Dental College, General Education 4: 221271.

Nakai, T. 1925. Critical note of Japanese ferns, with special references to the allied species. Botanical Magazine 39: 101-121.

Nakai, T. 1942. Notulae ad plantas Asiae orientalis (XX). Journal of Japanese Botany. 18: 281-292.

Nakai, T. 1952. A synoptical sketch of Korean flora. Bulletin of the National Science Museum, Tokyo 31: 1-152.

Nakaike, T. 1975. Enumeratio Pteridophytarum Japonicarum; Filicales. University of Tokyo Press, Tokyo.

Nakaike, T. 1992. New flora of Japan, Revised and enlarged ed. Dhibundo, Tokyo.

Nakato, N., M. Kato and B. D. Lin. 1995. A cytotaxonomic study of some ferns from Jiangsu and Zhejiang Province, China. Journal of Japanese Botany 70: 194-204.

Ohba, H. 1971. A taxonomic study on pteridophytes of the Bonin and Volcano Islands. Science Reports of the Tohoku Imperial
University, Series 4, Biology 36: 75-127.

Ohwi, J. 1957. Flora of Japan. Pteridophyta. Shinundo, Tokyo.

Park, M. K. 1975. Illustrated Encyclopedia of Fauna and Flora of Korea. Pteridophyta, vol. 16. Samhamunhwasa, Seoul.

Serizawa, S. 1976. A revision of the dryopteroid ferns in Japan and adjacent regions. Science Reports of the Tokyo Kyoiku Daigaku, Section B 16: 109-148.

Shing, K.-H. and J.-F. Cheng. 1990. New species of pteridophytes from Jiangxi province. Jiangxi Science 8(3): 43-49.

Sun, E.-M., J.-W. Jang, H.-T. Im and H.-D. Son. 2012. A short record for the distribution of two rare Korean ferns. Korean Journal of Plant Taxonomy 42: 167-170.

Tagawa, M. 1959. Coloured Illustrations of the Japanese Pteridophyta. Hoikusha, Osaka.

Tryon, A. F. and B. Lugardon. 1991. Spores of Pteridophyta. Springer-Verlag. New York.

Zhang, L. B., S. G. Wu, J. Y. Xiang, F. W Xing, H. He, F. G. Wang, S. G. Lu, S. Y. Dong, D. S. Barrington, K. Iwatsuki, M. J. M. Christenhusz, J. T. Mickel, M. Kato and M. G. Gilbert. 2013. Dryopteridaceae. In Flora of China, Vol. 2-3, Wu, Z. Y., P. H. Raven and D. Y. Hong (eds.), Beijing: Science Press; St. Louis: Missouri Botanical Garden Press. Pp. 541-724.

Zhang, L. B., L. Zhang, S. Y. Dong, E. B. Sessa, X. F. Gao and A. Ebihara. 2012. Molecular circumscription and major evolutionary lineages of the fern genus Dryopteris (Dryopteridaceae). BMC Evolutionary Biology 12: 180. 


\section{Appendix. Representative specimens examined.}

1) Dryopteris decipiens var. diplazioides (애기지네고사리)

KOREA. Gwangju: Mt. Wolgak, 22 Dec 2002, C.-H. Kim s.n. (JNU).

2) Dryopteris championii (제주지네고사리)

JAPAN. Kagawa: Utsumi-cho, Shinkentsu, 6 May 1976, T. Nakaike s.n. (KNU). Tokyo: Ongatamura, 23 Oct 1960, Y. Tanaka s.n. (KNU).

KOREA. Gwangju: Mt. Wokgak, 10 Jul 2008, C. S. Lee \& Y. S. Kim 080820, 080822 (KB). Gyeongnam: Isl. Mireuk, 3 Jul 2008, S.-J. Lee 800 (KB). Jeju: Donnaeko Valley, 21 Jul 2010, S.-J. Lee 1419 (SNU). Jeonnam: Mt. Dalma, 5 Jun 2009 , S.-J. Lee 1099 (KB); Yeongsan River, 21 May 2010, I. C. Hwang et al. 50250 (KB).

\section{3) Dryopteris kinkiensis (엷은지네고사리)}

JAPAN. Higo: Hitoyoshi, 8 Jul 1930, K. Mayebara 728 (KYO). Kii: Sano, 7 Sep 1930, Y. Awamoto s.n. (KYO). Kyoto: Hyakumanben, 15 Jun 1954, M. Tagawa 5764 (KYO). Omi: Mt. Hieizn, 20 May 1934, K. Yamamoto 3 (KYO). Oosaka: near Ootori, south of Sakai, 23 Sep 1950, M. Tagawa 3618 (KYO). Settu: Okamati near Oosaka, 10 Jun 1932, N. Ui s.n. (KYO). Sohiga: Tanakami-yama, 28 Oct 1971, S. Nitsuta s.n. (KYO). Tanba: Mononobe-mura, 17 Aug 1928, K. Nakai s.n. (KYO). Tikuzen: Akizuki-mati, 5 Jan 1934, K. Nakasima s.n. (KYO). Wakayama: Arita-gun, 14 Nov 1954, K. Mihashi s.n. (KYO).

KOREA. Gwangju: Mt. Wolgak, 15 Oct 2006, C. S. Lee \& Y. S. Kim 060653 (KB); 10 Jul 2008, C. S. Lee 080815 (KB). Jeju: Deokheung-sa, 27 Oct 2010, M.-O. Moon \& S.-H. Kang 1728-1 (KB); "in herbidis Quelpart", Aug 1907, U. Faurie 2152 (KYO);

4) Dryopteris fuscipes (큰지네고사리)

JAPAN. Yamaguchi: Kawakami, 29 May 1960, H. Mazaki s.n. (KNU).

KOREA. Gwangju: Mt. Wokgak, 29 Jul 2007, S.-J. Lee 1210 (KB); 29 Sep 2007, C. S. Lee \& Y. S. Kim 070508 (KB). Gyeongnam: Mt. Sanbang, 29 Mar 2008, G. Y. Chung 017 (KB); Mt. Songhak, 15 Oct 2009, H. Kim 5354 (KB). Jeju: Donnaeko Valley, 24 Oct 2007, C. S. Lee \& Y. S. Kim 070509-070511 (KB); 25 Aug 2009, C. S. Lee \& S. M. Eum 091691, 091692,091696 (KB); Gwaneum-sa, 6 Oct 2010, C. S. Lee \& Y. S. Kim 20101601 (KB); Seondol, 22 Sep 2008, C. S. lee 080757 (KB); 14 Sep 2009, K.-H. Tae et al. s.n. (KB); Suak Valley, 22 Oct 2009, S.-J. Lee et al. 09-P226 (KB); S.-J. Lee 1360, 1362 (KB). Jeonnam: Daemun-ri, 16 Mar 2008, N. S. Lee et al. 080672 (KB); Isl. Hong, 26 Jul 2008, C. H. Kim \& S. S. Choi 30184 (KB).

\section{5) Dryopteris erythrosora (홍지네고사리)}

JAPAN. Chiba: Kazusakameyama, 27 Jun 1975, M. Ishizuka s.n. (KNU). Yamaguchi: Kawakami, 29 May 1960, H. Mazaki s.n. (KNU).

KOREA. Chungnam: Seongju-ri, 15 Sep 2005, H. T. Im s.n. (CNU). Gyeongbuk: Isl. Ulleung, 7 Jun 1917, T. Nakai s.n. (SNU); 12 Jul 1937, P.-S. Toh \& H.-C. Shim s.n. (SNU); 18 Jul 1937, P.-S. Toh \& H.-C. Shim s.n. (SNU). Gyeongnam: Isl. Bijin, 9 Jul 1964, H. S. Lee s.n. (EWH); Yeongun-ri, 5 Nov 2006, Lee 2006-899 (SNU). Jeju: Donnaeko Valley, 30 May 2008, J. Lim et al. 100580, 100584 (KB); Gotjawal, 7 Oct 2006, G. Y. Chung et al. s.n. (ANH); Hannam-ri, 12 Aug 1999, K. M. Song s.n. (JNUB); Mt. Halla, 22 Jul 1954, T. H. Chung s.n. (SKK); Musucheon, 31 Jul 1999, S.-J. Lee 176 (SNU); Seondeoksa, 27 Feb 2008, J. Lim et al. 100020, 100022 (KB); Seongpanak, 31 Jul 1999, S.-J. Lee 164, 165 (SNU); Suak Valley, 25 Sep 2001, Lee 902 (SNU); Yeongsil, 2 Aug 1999, S.-J. Lee 203, 204 (SNU). Jeonnam: Isl. Daejang, 11 Jun 2012, H. T. Im et al 70191 (KB); Myeongsasip-ri, 8 Aug 2006, G. Y. Chung et al. s.n. (ANH); Isl. Yeoseo, 4 Aug 1981, without collector's name (KNU); 5 Aug 1981, without collector's name (KNU). Ulsan: Mt. Yonggok, 16 Apr 2005, J.-H. Park et al. 7644 (KB); 16 Apr 2005, J.-H. Pak et al. $7662(\mathrm{KNU})$

6) Dryopteris amurensis (아물고사리)

CHINA: Heilongjiang, Yichun, Dailing, 10 Sep 1954, Y. Zhang 14 (PE)

JAPAN: "Montagnes de Mashike", 23 Jul. 1892, U. Faurie 8319 (P). 
RUSSIA: without specific locality, 17 Jul-14 Aug 2002, B.-Y. Sun et al. 2377, 2417 (JNU).

7) Dryopteris formosana (홍노족제비고사리)

JAPAN. Fukuoka: Minamihata, Toki-dani, 12 Apr 1975, S. Tsutsui s.n. (KNU). Kawachi: Iwawakisan, 8 Jul 1928, Z. Tasiro s.n. (KYO). Omi: Isiyama, 26 Feb 1933, K. Yamamoto s.n. (KYO). Osumi: Isl. Yaku-sima, Jul 1900, U. Faurie 4554 (KYO); Mt. Nagata-dake, 8 Aug 1923, Z. Tasiro s.n. (KYO). Yamasiro: Mt. Daigo-yama, 27 Jul, 1928, K. Takeuti s.n. (KYO); Uzi, Mimurodo, 29 Oct 1929, G. Koidzumi s.n. (KYO).

KOREA. Jeju: Donnaeko Valley, 22 Sep 2006, C. S. Lee \& Y. S. Kim 060649, 060650 (KB); 30 May 2008, J. Lim et al. 100575 (KB); Jeolmul, 13 Feb 2009, G.-H. Nam 09-P214 (KB); Seondeoksa, 22 Oct 2009, S.-J. Lee 1373 (KB); 27 Feb 2008 , J. Lim et al. L00021 (KB).

PHILIPPINES. Luzon: Mt. Murnay, 4 Dec 1975, K. Iwatsuki et al. 851 (KYO).

TAIWAN, Taihoku: Mt. Taihei-zan, 25 May 1933, J. Ohwi 2244 (KYO). Taityu: Arisan, Dec 1914, U. Faurie s.n. (KYO); Bunkikiyo, May 1914, Y. Faurie 385 (KYO); Iwaiyama, 3 Jul, 1933, J. Ohwi 3504 (KYO); Kodama-yama, 21 Aug 1934, M. Tagawa 587, 591 (KYO). Takao: Mt. Daibusan, 10 May 1933, J. Ohwi 1862 (KYO). Tikuzen: Utino-mura, 2 Apr 1933, K. Nakasima 79 (KYO). Tusima: Mt. Ariake-yama, 31 Jul 1933, K. Nakasima 100 (KYO).

\section{8) Dryopteris varia (족제비고사리)}

CHINA. Guandong: Hoyuen, Kwai Shan, 112 Apr 1938, W. T. Tsang 28942 (KYO); Tapu, Taimo Shan, 14 Jul 1932, W. T. Tsang 21175 (KYO). Fujian: Isl. Shark Peak, 1910, W. Millward 10934 (KYO).

JAPAN. Ehime: Mii-gun, Saizyo, 30 Oct 1939, K. Oti 37 (KYO). Higo: Issyoti, 10 Dec 1916, K. Mayebara s.n. (KYO). Hizen: Tiwata-mura, 20 Nov 1933, T. Hamada s.n. (KYO). Kagoshima: Isl. Tanegashima, 29 Dec 1958, K. Iwatsuki 4166 (KYO); Isl. Yakushima, 3 Aug 1957, K. Iwatsuki 2629 (KYO); Kaimon-cho, 20 Jul 1956, K. Iwatsuki s.n. (KYO); Sata-cho, 7 Aug 1956 , M. Tagawa \& K. Iwatsuki 1347 (KYO); Uchinoura-cho, 4 Aug 1956, M. Tagawa \& K. Iwatsuki 4247 (KYO). Kii: Arii-mura, 20 Mar 1930, T. Koide s.n. (KYO); Doro-hattyo, 30 May 1951, G. Nakai 5199 (KYO); Matubara, 15 Oct 1928, Y. Tutiga s.n. (KYO); Setokanayama-mura, 4 Apr 1931, M. Tagawa 2409 (KYO). Kochi: Aki-gun, 22 Nov 1955, M. Tagawa \& K. Iwatsuki 620 (KYO); Hata-gun, 13 Nov. 1954, M. Tagawa 5845 (KYO); Hayama-mura, 8 Feb 1972, S. Mitsuta s.n. (KYO); Mt. Yokogura, 22 Dec 1972, S. Mitsuta s.n. (KYO). Kumamoto: Kuma-mura, Oose, 3 Aug 1960, M. Tagawa \& K. Iwatsuki 3629 (KYO); Minamata, 1 Jun 1961, M. Kido 3858 (KNU); Ogawa-cho, Warabi-no, 21 Oct 1978, S. Mitsuta \& Y. Beppu 28 (KYO). Mie: Kitamuro-gun, 3 Nov 1952, M. Tagawa 4793 (KYO). Nagasaki: Isl. Hirato, 21 Jul 1979, M. Fujita \& S. Mitsuta 117 (KYO); Isl. Hukue, Oohamamura, 17 Apr 1956, M. Hutoh 14212 (KYO); Mt. Gongenyama, 27 Jul 1979, M. Fujita \& S. Mitsuta 441, 464 (KYO); Tagahama, 16 Jun 1907, T. Makino 92914 (KYO). Ryukyu: Isl. Amami-Ooshima, 29 Jul 1959, K. Iwatsuki 4711 (KYO); Isl. Kume-sima, 6 Aug, 1932, S. Tawada 112 (KYO); Isl. Okinawa, 15 Jul 1938, Y. Taira 355 (KYO). Satuma: Shimokoshiki, 14 Mar 1958, K. Kawanabe 3691 (KYO). Shimane: Tachikue-kyo, 31 Jul 1961, N. Kitagawa 5307 (KYO). Tosa: Mt. Konomine, 4 Aug 1930, M. Tagawa s.n. (KYO); Utiuta-mura, 7 Nov 1937, T. Yosinaga s.n. (KYO). Wakayama: Mt. Nachii, 4 Dec 1955, M. Tagawa \& K. Iwatsuki 693 (KYO); Mt. Ooto-mura, 10 Aug 1965, G. Murata \& F. Konta 52 (KYO).

KOREA. Jeju: Anduk Valley, 3 Nov 2000, S.-J. Lee 582, 590-595, 605-608, 622, 623 (SNU); Jejigioreum, 24 Oct 2009, S.J. Lee 1427 (KB), 1428 (SNU); Jungmun-dong, 15 Aug 1939, H. D. Chang 399 (KYO); Seogwipo-si, 23 Apr 1932, G. Koidzumi s.n. (KYO).

PHILIPPINES. Lozun: Mt. Sicapoo, 6 Dec 1975, K. Iwatsuki et al. 886 (KYO). Nantou: "the neighborhood of the Kuantaochi Branch of the Nengkao Forestry Institutino", 14 May 1961, T. Shimizu 12709 (KYO).

TAIWAN. Kwarenko: Kwaren-gun, between Sakahen and Kirai, 10 Mar 1940, M. Tagawa 3530 (KYO). Sanhsia: Mt. Yuan Shan, 23 Aug 1964, M. Tamura \& H. Koyama 23487, 23489 (KYO). Sintiku: Byoritu-gun, Dora, 8 Aug 1923, Y. Simada 5146B, 5170B (KYO); Koko, 8 Aug 1923, Y. Simada 5145B (KYO); Nansyo, 9 Feb 1923, Y. Simada $146 D$ (KYO). Taihoku: "in silvis Tamsui", May 1904, U. Faurie 654 (KYO); Sizangan near Taihoku, 20 Jun 1903, S. Nagasawa s.n. (KYO); Togokei prope Agyoku, 5 Aug 1934, M. Tagawa 233 (KYO); Urai, Apr 1914, U. Faurie s.n., 91, 106 (KYO). Taito: Kwanzan-gun, near Kakayo, 4 Mar 1940, M. Tagawa 3139 (KYO); Taito-gun, near Kinko, 6 Feb 1940, M. Tagawa 2769 (KYO). Takao: Hoki, 19 Nov $1931, S$. Okamoto s.n. (KYO); Rokki-syo, Doryuwan, 23 Dec 1938, M. Tagawa 1655 (KYO); Sangokei, 10 Dec 1938, M. Tagawa 1376 (KYO). 


\section{9) Dryopteris podouensis (큰족제비고사리)}

JAPAN. Iyo: Saijoo-shi, Kamomachi, 3 Sep 1960, K. Oti 15379 (KNU). Wakayama: Shirahama-cho, Rinkai, 15 Mar 1987 , J.-H. Park \& S. Fujii 701 (KNU).

KOREA. Gyeongnam: Geoje-si, Galgot-ri, 12 Aug 2000, S.-J. Lee 470-475, 478-487 (SNU); Isl. Gadeok-do, Yul-ri, 12 Aug 1999, Yoo \& Kwak s.n. (SNU); Mijo-myeon, 22 Sep 1993, Lee s.n. (SNUA). Jeju: Without locality and date, Lee 9883 (SNUA); without specific locality, 26 Jul 1962, S.-Y. Oh 1712 (KNU); Anduk Valley, 3 Oct 1985, Lee s.n. (SNUA); 3 Sep 2000, S.-J. Lee 583-589, 602, 603, 611-613, 616-619 (SNU); Chunjeyeon Waterfall, 1 Aug 1999, S.-J. Lee 193, 194-200 (SNU); Donnaeko Valley, 14 Oct 1988, Lee s.n. (SNUA); Dopyeong-dong, 2 Sep 2000, S.-J. Lee 563, 564, 566-578 (SNU); Manjanggul, 30 Jul 1999, S.-J. Lee 133-141 (SNU); Seongpanak, 7 Jun 2000, Kim s.n. (SNU); Chuja-myeon, without date, Lee s.n. (SNUA). Jeonnam: Bongrae-myeon, Yenae-ri, 13 Jun 2000, S.-J. Lee \& J.-S. Song s.n. (SNU); Goheung-gun, 10 Aug 1993, Lee \& Lee (SNUA); Isl. Geomun-do, 18 Aug 1964, Lee et al. s.n. (SNUA); Isl. Hong-do, 16 Nov 1964, Lee et al. s.n. (SNUA); Isl. Judo, 15 Aug 1964 , Lee et al. s.n. (SNUA); Isl. Oenaro-do, 13 Jun 2000, S.-J. Lee 340 (SNU); Mt. Jiri, 21 Jul 2000, Lee \& Kim s.n. (SNU); Songgimyeon, Ttangkkeut, 12 Jun 2000, S.-J. Lee 333, 334 (SNU); Wando-gun, Geumgokri Valley, 17 Jul 2004, Y. H. Lee 03011 (CNU); Wando-gun, Jangjwa-ri, 12 Jun 2000, Song s.n. (SNU).

10) Dryopteris sacrosancta (애기족제비고사리)

CHINA. Shandong: Lanchou, 29 Sep 1936, I. Namikawa s.n. (KYO).

JAPAN. Iyo: Saijoo-shi, Iioka, 2 Sep 1960, K. Oti 15356 (KNU).

KOREA. Chungbuk: Mt. Buyong, 8 Aug 2000, S.-J. Lee 432-440 (SNU); Mt. Gaji, 7 Aug 1963, S.-Y. Oh 3343-3345 (KNU); Mt. Naeyeon, 13 Aug 2000, S.-J. Lee 495-498, 500, 501 (SNU); Mt. Seoun, 2 Apr 2002, H. Shin \& Y. Lim 17 (KB); Mt. Worak, 11 Sep 1988, J. H. Lee s.n. (SNU). Chungnam: Mt. Gwangdeok, 19 Oct 2005, Y.-D. Kim et al. 0390-1 (KB); Mt. Gyeryong, 13 Jul 1999, Lee 98, 111 (SNU); Mt. Hwangmae, 18 Jun 1998, T. Kim et al. 1224 (JNU); Mt. Oseo, 4 Sep 1997, S. K. Lee 5 (SNU); Mt. Seonggeo, 4 Jun 1998, S. C. Ko \& H. Y. Bae 0606 (KB). Daegu: Mt. Biseul, 4 Jul 2000, S.-J. Lee 00-18 (SNU). Gyeongbuk: Mt. Juwang, 15 Aug 2008, S.-J. Lee 1228 (KB); Mt. Naeyeon, 15 Jul 1962, S.-Y. Oh 172, 173, 180 (KNU); Seongju-gun, Geumsumyeon, without date and collector's name (KNU). Gyeonggi: Mt. Soyo, 3 Jun 1999, S.-J. Lee 79 (SNU); Mt. Taehwa, 29 May 1999, S.-J. Lee 29 (SNU); Sohol-eup, Gomo-ri, 8 Apr 2006, C. S. Lee 070501 (KB). Gyeongnam: Hadong-gun, Uisinmaeul, 22 Jul 2000, S.-J. Lee 361, 362 (SNU); Mt. Gaya, 1 Aug 1960, S.-Y. Oh 3603, 3604 (KNU); Mt. Jiri, 21 Jul 2000, S.-J. Lee 358 (SNU); Mt. Warong, 16 Oct 1999, N. S. Lee et al. 1510 (KB); Yangsan-gun, Gori, 4 Jul 1981, Y.-H. Chung s.n. (SNU). Jeju: Seoho-dong, 20 Aug 2006, C. S. Lee \& Y. S. Kim 060660, 060663 (KB). Jeonbuk: Mt. Cheontae, 1 Oct 2006, B.-Y. Sun 0261 (KB); Mt. Dukyo, 16 Aug 2000, S.-J. Lee 506 (SNU); Mt. Duseung, 1 Oct 2006, C.-H. Kim 0251 (KB); Mt. Naebyeon, 4 Aug 2000, Lee 374, 375, 377, 378, 385, 386, 394 (SNU); Mt. Naeyeon, 13 Aug 2000, S.-J. Lee 495, 499-501, 518 (SNU); Mt. Soyo, 9 Aug 2006, B.-Y. Sun 0630 (KB). Jeonnam: Gokseong-eup, 20 Oct 2007, H. Kim 3724 (KB); Mt. Gaya, 11 Aug 2000 , S.-J. Lee 452 (SNU); Mt. Jiri, 9 May 1987, J. H. Lee s.n. (SNU); 8 May 1987, H. W. Lee s.n. (SNU); Wacheon-ri, 21 Oct 2006, H. Kim 2839 (KB); Wolbong-ri, Goribong, 31 Oct 2007, H. Kim 3796 (KB). Seoul: Mt. Bukhan, 9 Aug 2000, Lee 441, 442, 444446, 448 (SNU); Mt. Gwanak, 29 Jun 1999, Lee 81 (SNU).

\section{1) Dryopteris bissetiana (산족제비고사리)}

JAPAN. Kii: Owase-shi, 23 Aug 1958, R. Ito 1284 (KNU).

KOREA. Chungbuk: Mt. Buyong, 8 Aug 2000, Lee \& Lee s.n. (SNU); Mt. Sokri, 2 Oct 1999, Lee s.n. (SNU). Chungnam: Mt. Gyeryong, 13 Jul 1999, Lee 351 (SNU); Mt. Gaya, 6 May 1994, Moon 64 (SNU); Mt. Oseo, 1 Aug 1997, S. K. Lee 3 (SNU). Daegu: Gongsan Dam, 12 Jan 2000, S.-W. Lee s.n. (KNU); Mt. Biseul, Yugasa, 4 Jul 2000, Kim \& Kwak s.n. (SNU). Gangwon: Geunduk-myeon, 12 Jul 2000, Park et al. s.n. (SNU); Mt. Geombong, 13 Jul 2000, Park et al. s.n. (SNU); Mt. Seokbyeong, 12 Apr 2002, C.-W. Park et al. 050 (SNU); Yeongok-myeon, Lee s.n. (SNUA). Gyeongbuk: Isl. Ulleung, 26 Jul 1961, Lee s.n. (SNUA); Mt. Juwang, 13 Jun 2000, Kwak s.n. (SNU); Mt. Naeyeon, 16 Apr 1980, without collector's name (KNU); 13 Aug 2000 , Lee 494, 503 (SNU). Gyeonggi: Gwangreung, 2 Jul 1999, S.-J. Lee 94 (SNU); Mt. Cheonma, 30 May 1999, S.-J. Lee 30 (SNU); Mt. Taehwa, 10 Apr 1983, H. C. Shin s.n. (SNU). Gyeongnam: Go-ri, 4 Jul 1981, Chung s.n. (SNU); Isl. Gadeok-do, 12 Aug 1999, Yoo \& Kwak S.n. (SNU); Mt. Kaya, 11 Aug 2000, Lee 453 (SNU). Jeju: Bangseonkyo, 31 Jul 1999, Lee 166, 167, 169171 (SNU); Dopyeng-dong, 2 Sep 2000, Lee 565 (SNU); Manjanggul, 30 Jul 1999, Lee 138-1 (SNU); Musucheon, 31 Jul 1999, 
Lee 180 (SNU); Seongpanak, 7 Jun 2000, Kim s.n. (SNU); Suakgyegok, 3 Sep 2000, Lee 628 (SNU); Yeongsil, 2 Aug 1999, Lee 207, 209, 218, 219, 221, 222 (SNU); 1 Sep 2000, Lee 547 (SNU). Jeonbuk: Mt. Byeon, 7 May 1993, H. Won 93-48 (SNU); Mt. Duseung, 1 Oct 2006, C.-H. Kim 0274 (KB); Mt. Naebyeon, 4 Aug 2000, Lee 367-369, 371-373, 376, 383, 384, 387-390, 392394 (SNU). Jeonnam: Isl. Geomun-do, 18 Aug 1964, Lee et al. s.n. (SNUA); Isl. Jin-do, Uisin-myeon, 4 Oct 1993, Lee \& Lee s.n. (SNUA); Isl. Oenaro-do, 13 Jun 2000, Lee \& Song s.n. (SNU); Mt. Baekun, 12 May 1995, E.-H. Han 2 (SNU); Mt. Duryun, 12 Jun 2000, Lee 315-319, 322-329 (SNU); Mt. Jiri, 16 Aug 1960, Lee s.n. (SNU); 15 Aug 1985, Lee s.n. (SNUA); 21 Jul 2000, Lee \& Kim s.n. (SNU); Wando-eup, Jangjwa-ri, 12 Jun 2000, Song s.n. (SNU). Seoul: Mt. Bukhan, 9 Aug 2000, Lee 447 (SNU). Mt. Gwanak, 25 Sep 1982, Kim et al. s.n. (SNUA).

\section{2) Dryopteris saxifraga (바위족제비고사리)}

KOREA. Chungbuk: Mt. Baekun, 4 Apr 1993, Won 93-2-22 (SNU); Mt. Seonggeo, 4 Jun 1998, S. C. Ko \& H. Y. Bae 0555 (KB); Mt. Sokri, 2 Oct 1999, Lee 264 (SNU). Chungnam: Deoksan-myeon, 1 Sep 1997, H. C. Shin et al. 901046 (KB); Mt. Gyeryong, 13 Jul 1999, Lee 112, 113, 116-120 (SNU); Mt. Taejo, 10 Oct 1988, Kim s.n. (SNU); Mt. Wolak, 16 May 1986, Yun s.n. (SNU). Gangwon: Geunduk-myeon, 12 Jul 2000, Park et al. s.n. (SNU); Inje-eup, 5 Sep 2000, Lee \& Kim s.n. (SNU); Mt. Baekun, 20 Mar 1993, Won 93-1-5, 93-1-6 (SNU); Mt. Geombong, 13 Jul 2000, Park et al. s.n. (SNU); Sacheon-myeon, 28 Sep 2007, J. Lee et al. 0775045 (KB). Gyeongbuk: Mt. Hwaak, 19 Oct 2007, J.-H. Kim \& Y.-H. Kim s.n. (KB); Mt. Hwangak, 19 Sep 1993, Park s.n. (SNU); 15 Oct 1993, Park s.n. (SNU); Mt. Joryeong, 20 Sep 1987, Kim s.n. (SNU); Mt. Juheul, 11 Apr 1987, Kim s.n. (SNU); 4 Nov 1987, Kim s.n. (SNU); Mt. Juwang, 13 Jun 2000, Kwak s.n. (SNU). Gyeonggi: Gwangreung, 12 Apr 1977, Lee s.n. (SNUA); 28 Aug 1977, Lee s.n. (SNUA); Jinjun-eup, Suribong, 2 Jul 1999, Lee $94-97$ (SNU); Mt Baekun, 13 Jul 2000, Lee 350, 352, 353 (SNU); Mt. Cheonggye, 17 Aug 2000, Lee 520-523, 525, 533-535, 537 (SNU); Mt. Chukryeong, 5 Apr 2000, Lee 303 (SNU); Mt. Chunma, 10 May 1999, Lee \& Lee 21-26 (SNU); 12 May 1999, Lee 1-20 (SNU); 30 May 1999, Lee \& Lee 30-33, 35-48 (SNU); 5 Apr 2000, Lee 304-307 (SNU); Mt. Gwanggyo, 23 Sep 1964, Lee et al. s.n. (SNUA); Mt. Jugeum, 4 Nov 1984, Kim s.n. (SNU); Mt. Mugap, 5 Aug 1991, Park et al. 84, 85 (SNU); Mt. Namhan, 4 Sep 1986, Kim s.n. (SNU); Mt. Taehwa, 29 May 1999, Lee et al. s.n. (SNU); Mt. Unak, 4 Apr 1992, Mun 11 (SNU); 25 Apr 1992 , Mun 10 (SNU); Taean-eup, 22 May 1982, Um et al. s.n. (SNUA). Gyeongnam: Isl. Gadeok-do, 12 Aug 1999, Yoo \& Kwak s.n. (SNU); Mt. Kaya, 11 Aug 2000, Lee 451, 454, 456-458, 463, 466-468 (SNU); Mt. Noja, 6 Jun 1997, D. W. Lim \& I. C. Hwang 0393002 (KB). Jeju: Bangseonkyo, 31 Jul 1999, Lee 172-174 (SNU); Donnaeko, 25 Nov 1987, Lee s.n. (SNUA); Musucheon, 31 Jul 1999, Lee 177-179 (SNU); Seoho-dong, 20 Aug 2006, C. S. Lee \& Y. S. Kim 060661, 060662 (KB); Seongpanak, 7 Jun 2000, Kim s.n. (SNU); Yeongsil, 2 Aug 1999, Lee 205, 206, 208, 210, 214-217, 223 (SNU); 1 Sep 2000, Lee 540, 542, 546, 548-552, 554, 579 (SNU); Yeongsil Valley, 18 Sep 2008, J. Lim \& S.-J. Lee 101032 (KB). Jeonbuk: Asan-myeon, 12 Aug 2008, S.-J. Lee 1222 (KB); Mt. Deokyu, 16 Aug 2000, Lee 505, 514 (SNU); Mt. Mai, 5 Aug 2000, Lee 425, 426 (SNU); Mt. Naejang, 4 Aug 2000, Lee 395-409, 411, 412, 414, 416, 417, 419, 420 (SNU). Jeonnam: Hwasun-gun, Nam-myeon, 6 Sep 2006, H. H. Hong et al. 040199 (KB), 040229 (KB); Mt. Jiri, 18 Jul 1962 Cha s.n. (SNU); 18 Jul 1969 Kim s.n. (SNU); 4 Jul 1982 Lee \& Jang s.n. (SNUA); 8 May 1987 Kim s.n. (SNU); 9 May 1987 Sim s.n. (SNU); Samgi-myeon, Chailbong, 27 Sep 2005, C.-W. Park et al. 2005-392 (KB); Hyeongjebong, 24 Apr 2005, C.-W. Park et al. 2005-025 (KB). Seoul: Mt. Bukhan, 9 Aug 2000, Lee (SNU); Mt. Gwanak, 29 Jun 1999, Lee 82 (SNU).

\section{3) Dryopteris saxifragivaria (광릉족제비고사리)}

KOREA. Gyeonggi: Mt. Cheonggye, Yetgol, 17 Aug 2000, Lee 524, 526, 528 (SNU); Mt. Chunma, 30 May 1999, Lee \& Lee 34 (SNU); Mt Baekun, 13 Jul 2000, Lee 354 (SNU). Gyeongnam: Mt. Kaya, 11 Aug 2000, Lee 447, 453, 455 (SNU). Jeju: Yeongsil, 1 Sep 2000, Lee 539, 541, 543, 545, 553, (SNU). Jeonbuk: Mt. Mai, Isanmyo, 5 Aug 2000, Lee 427 (SNU); Mt. Naejang, 4 Aug 2000, Lee 410, 413, 418, 419, 421 (SNU). 